شناسايى و بررسى تغييرات سطح زير كشت محصولات زراعى روستاى حسين آباد ميشمست با استفاده از تصاوير ماهوارهاى

حميده صدوقى '"، طاهر رجايى' و نيما روحانى'

(تاريخ دريافت: 09/1/1/1 ؛ تاريخ بذيرش: 99/0/0 1)

جكيده

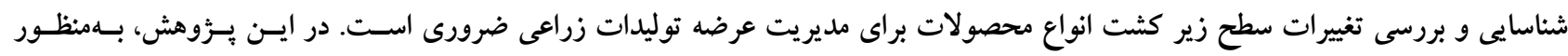

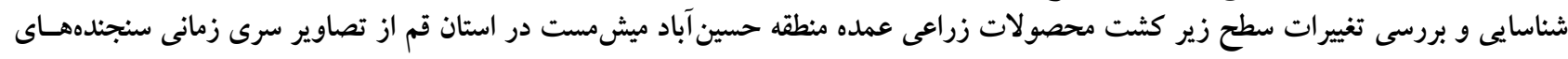

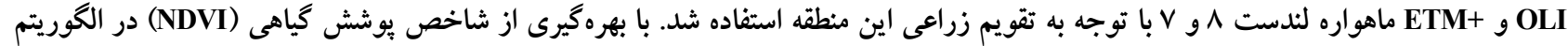

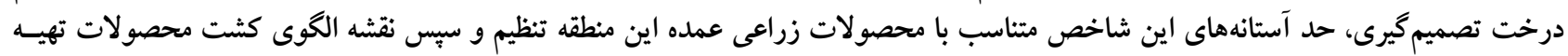

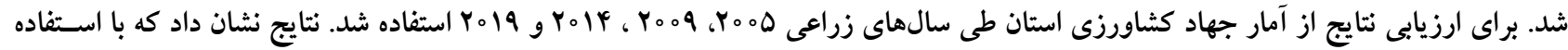

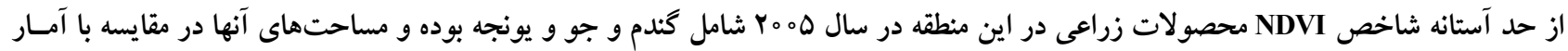

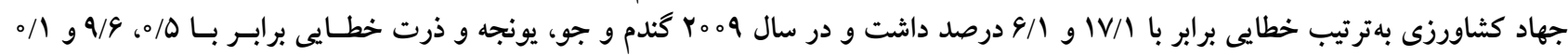

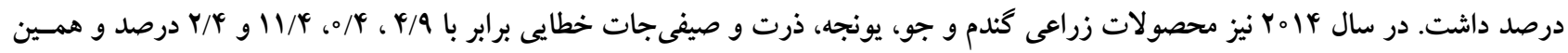

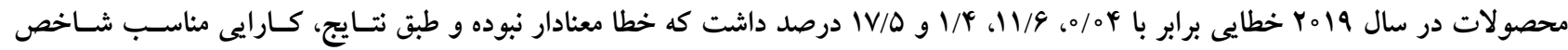
NDVI

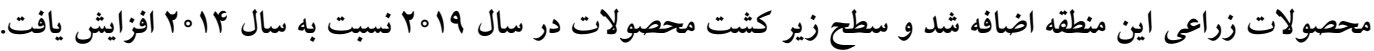

وازههاى كليدى: شاخص NDVI، فنولوزى، الكوى كشت، درخت تصميم گيرى، حسين آباد ميشمست 
محصولات زراعى در خارج و داخل كشـور انجـام شـــه اسـت. از

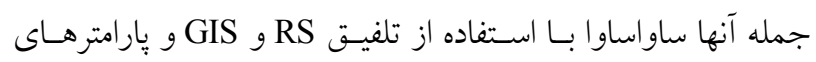
مديريت، سطح زير كشت بــنج را بـا استفاده از تصـاوير مـاهواره با تفكيك مكانى سז متـر و و (India Remote Sensing satellite)IRS

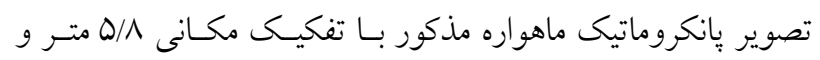

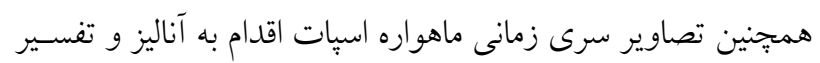

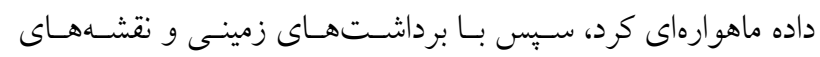

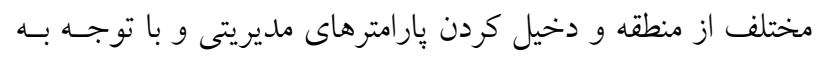

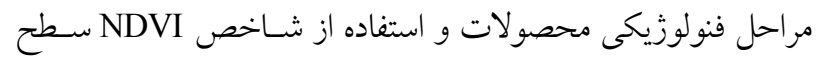

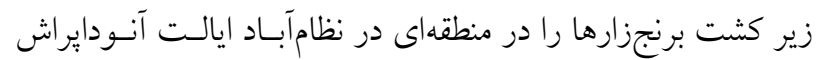

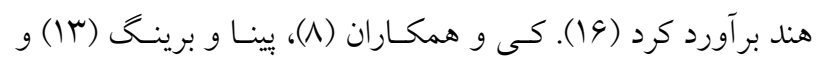

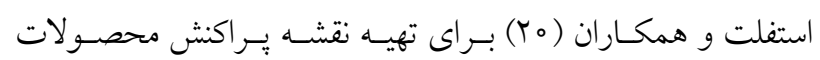

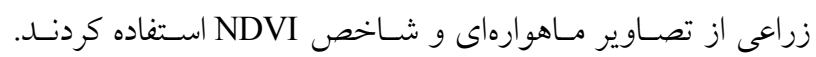
بندينى و همكاران براى تهيه نقشه محصولات كثاورزى در منطقـهـ

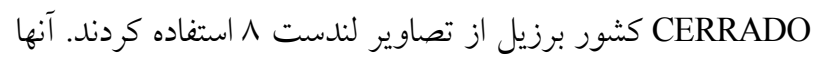

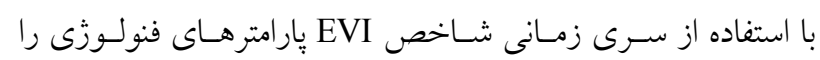

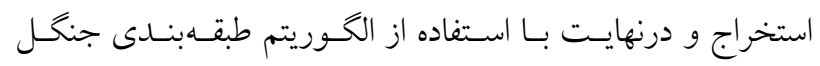

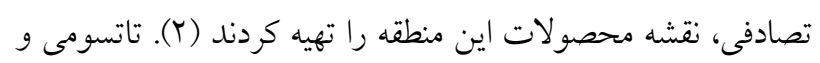

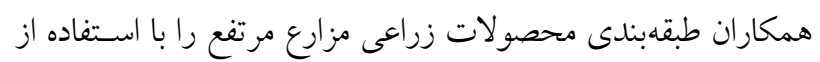

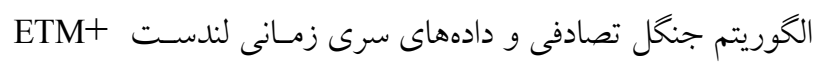

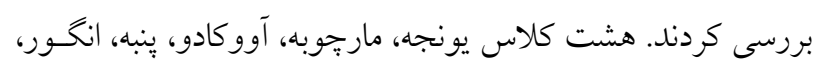

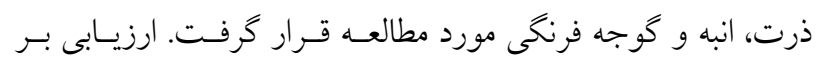

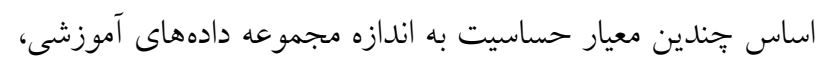

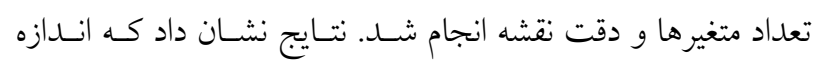

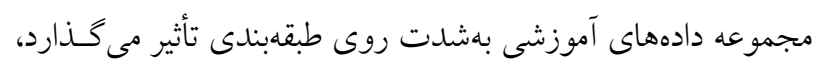

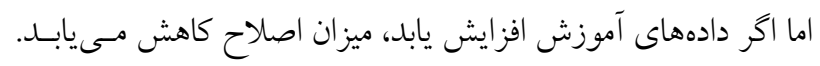

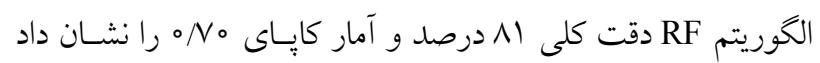

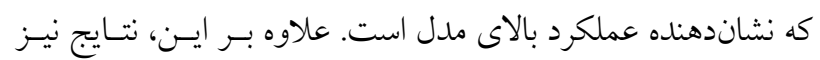

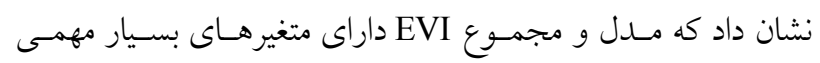

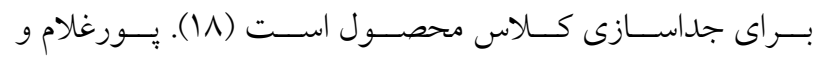

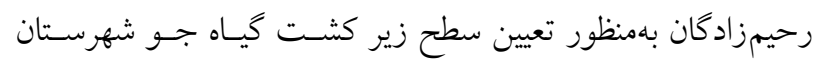
تربت حيدريه از تصاوير جندزمانه لندست ^و شاخص هاى گياهى

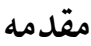

تخمين سطح زيــر كشـت محصـولات زراعى در برنامسهريـزى و

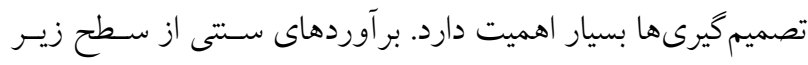

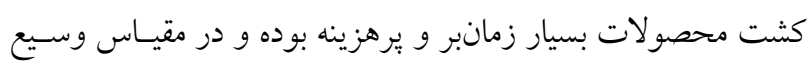

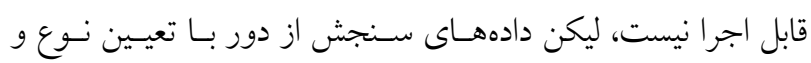

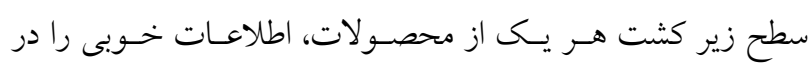

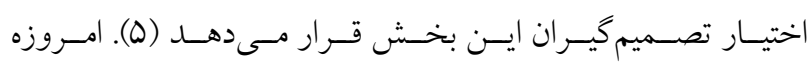

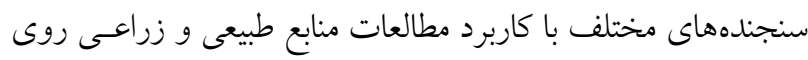

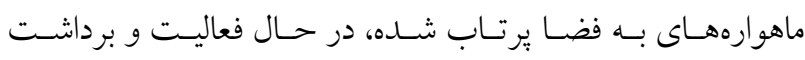

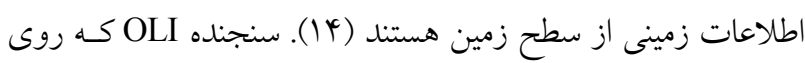

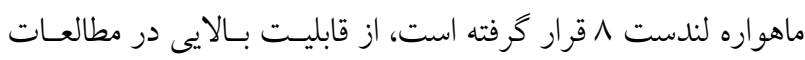

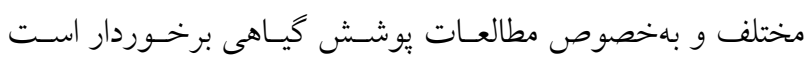

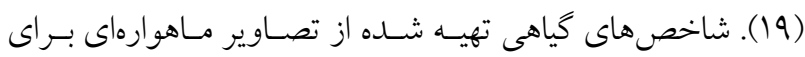

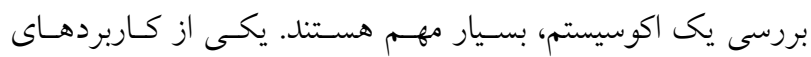

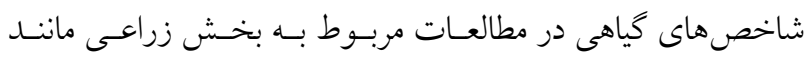
تعيين الكوى كشت، سلامت محصول و...اسـت (Vو و 19). در ميـان

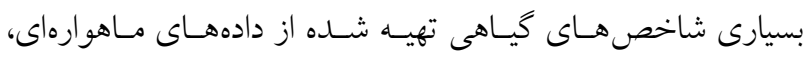

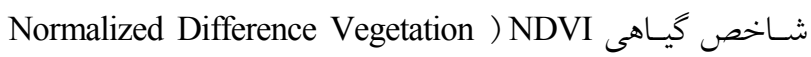
Index بهخصوص مطالعات مربوط به بخش زراعى است (V). از آنجـا كـه

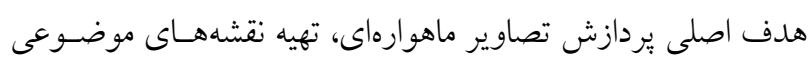

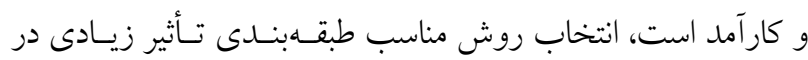

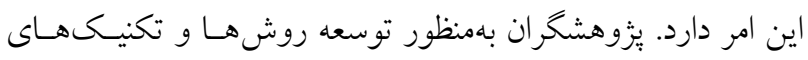

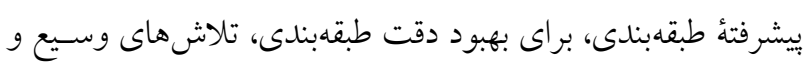

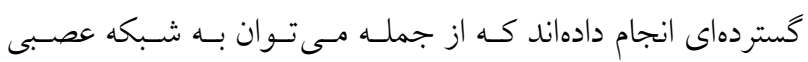

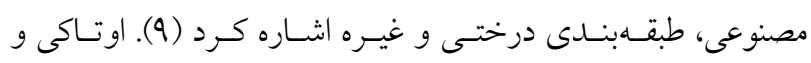

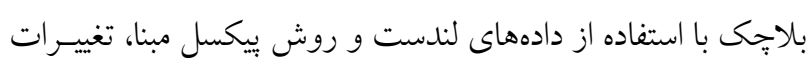

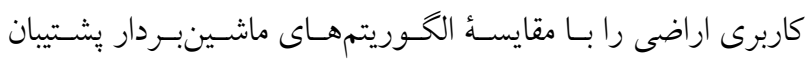

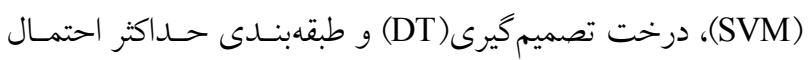
ارزيابى كردند، كه عملكرد الكوريتم درخت تصـميم كيـرى (MLC)

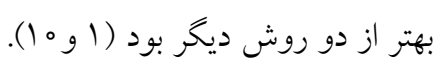

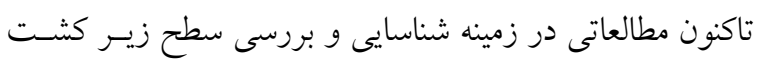


باندى انجام شد. نتايج نشان داد كه روش حداكثر احتمال بهعنوان روش متتخب طبقهبندى در برنج انتخاب و سطح زير كشت برنج

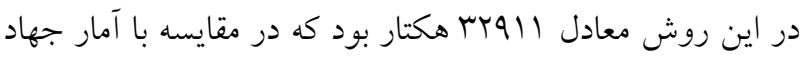

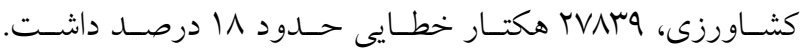
همجنــين سطح زيـر كثـت سـويا در روش كمتـرين فاصـله از

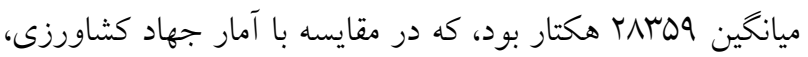

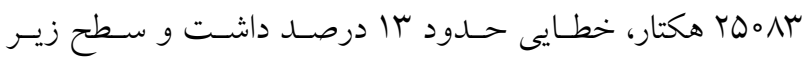
كشت برنج نسبت به سالهاى قبل افزايش ولى سويا كاهش يافتسه

أكاهى از انواع محصولات و وضعيت سـطح زيـر كشـت آنهـا بلعنوان اولين كام در سـاماندهى الحـوى كثـت مطـرح مسى شـود.

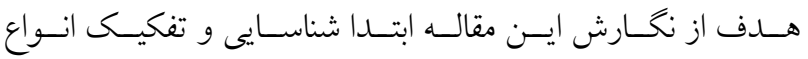

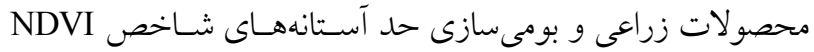

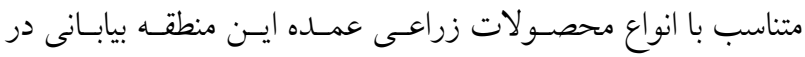

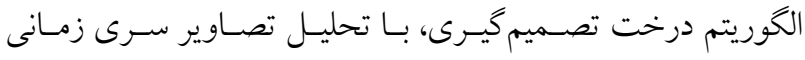

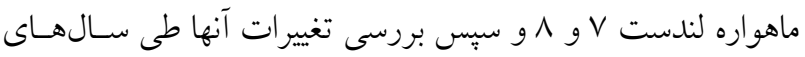

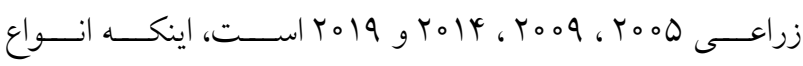

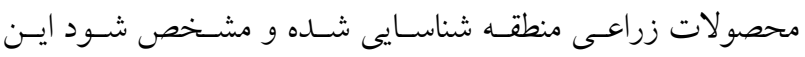
محصولات به جهه صورتى تغيير كرده است.

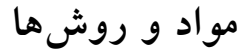

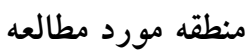

حسين آباد ميشمست، روستايى از توابع بخش مركزى شهرستان

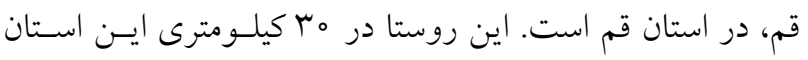

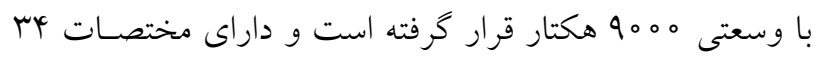

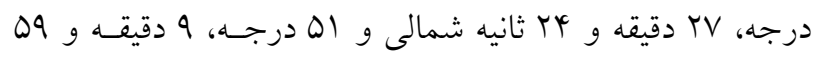

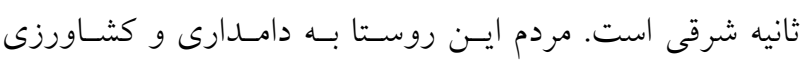

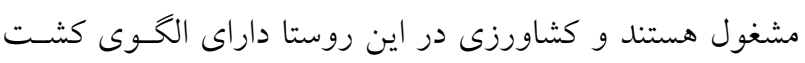

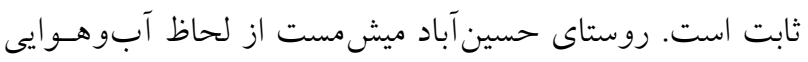
بسيار گرموخشك است و بهدليـل گرمسير بـودن ايسن روستستا، زراعت آبى صورت مى گيرد. در شكل ا موقعيت منطقـه مـورد مطالعه نمايش داده شده است.
در طـول دوره زمـانى يـكسـاله و همجنـين شناسـايى زمـان اوج

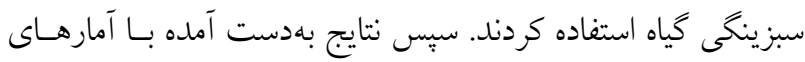

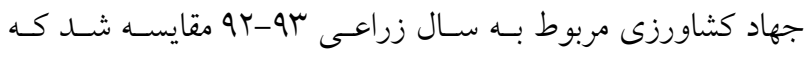

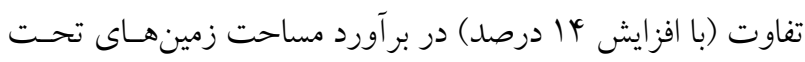

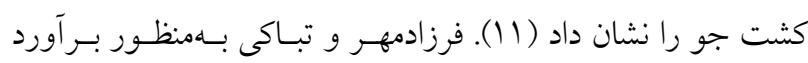

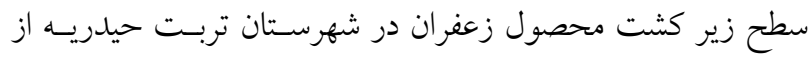
تصاوير لندست ^و و شاخص هاى گيـاهى اسـتفاده كردنـــ. در ايسن

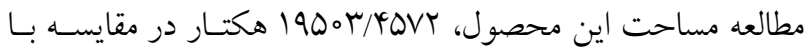

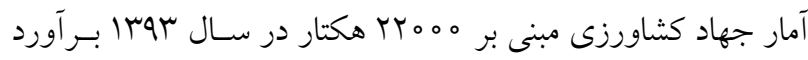

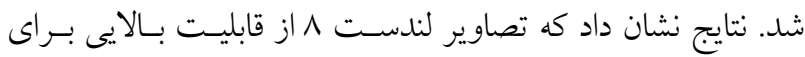

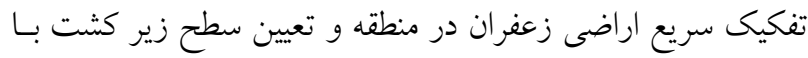
دقت بهنسبت مناسـب در مقيـاس منطقـهاى برخـوردار اسـت (؟).

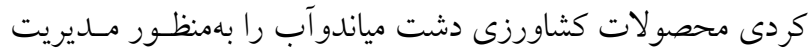

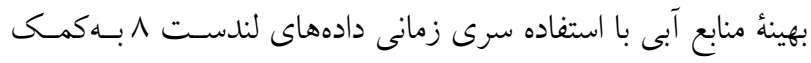

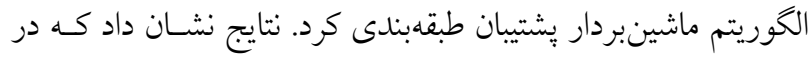
فرايند طبقهبندى از تركيب باندها، شاخص هاى كيـاهى GNDVI و و

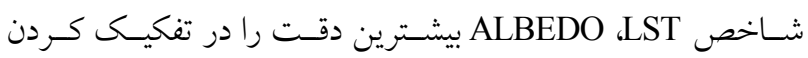

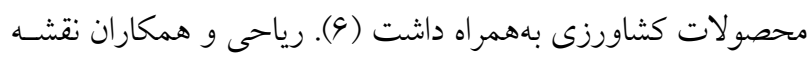
الكوى كشت محصولات زراعى غالـب ناحيـه لنجانـات در اسـتان

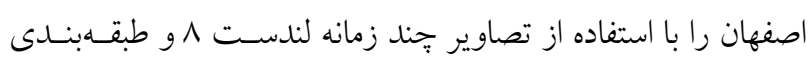

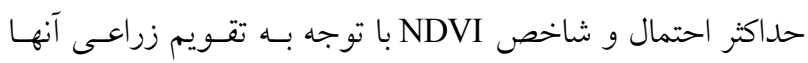

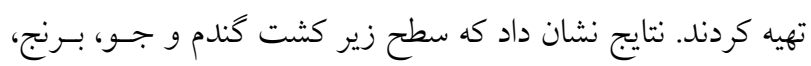

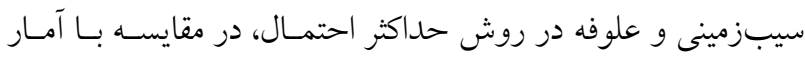

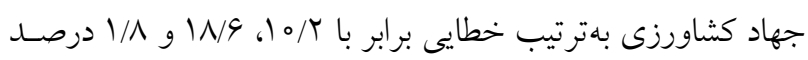
داشت. اما استفاده از شـاخص NDVI در مقايسـه بـا آمـار جهـاد

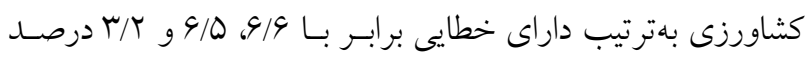

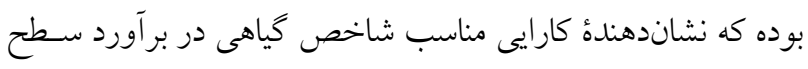

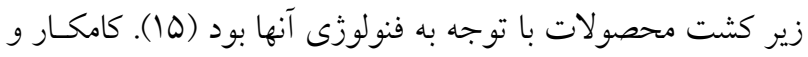
همكاران بهمنظور شناسايى و تعيين سطح زيــر كشـت دو محصـول

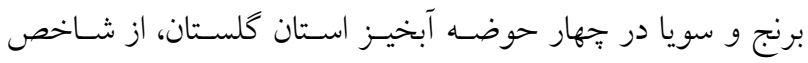
NDVI لازم، تركيبات باندى، تركيبات رنخى، موزائيك تصاوير و محاسبات 


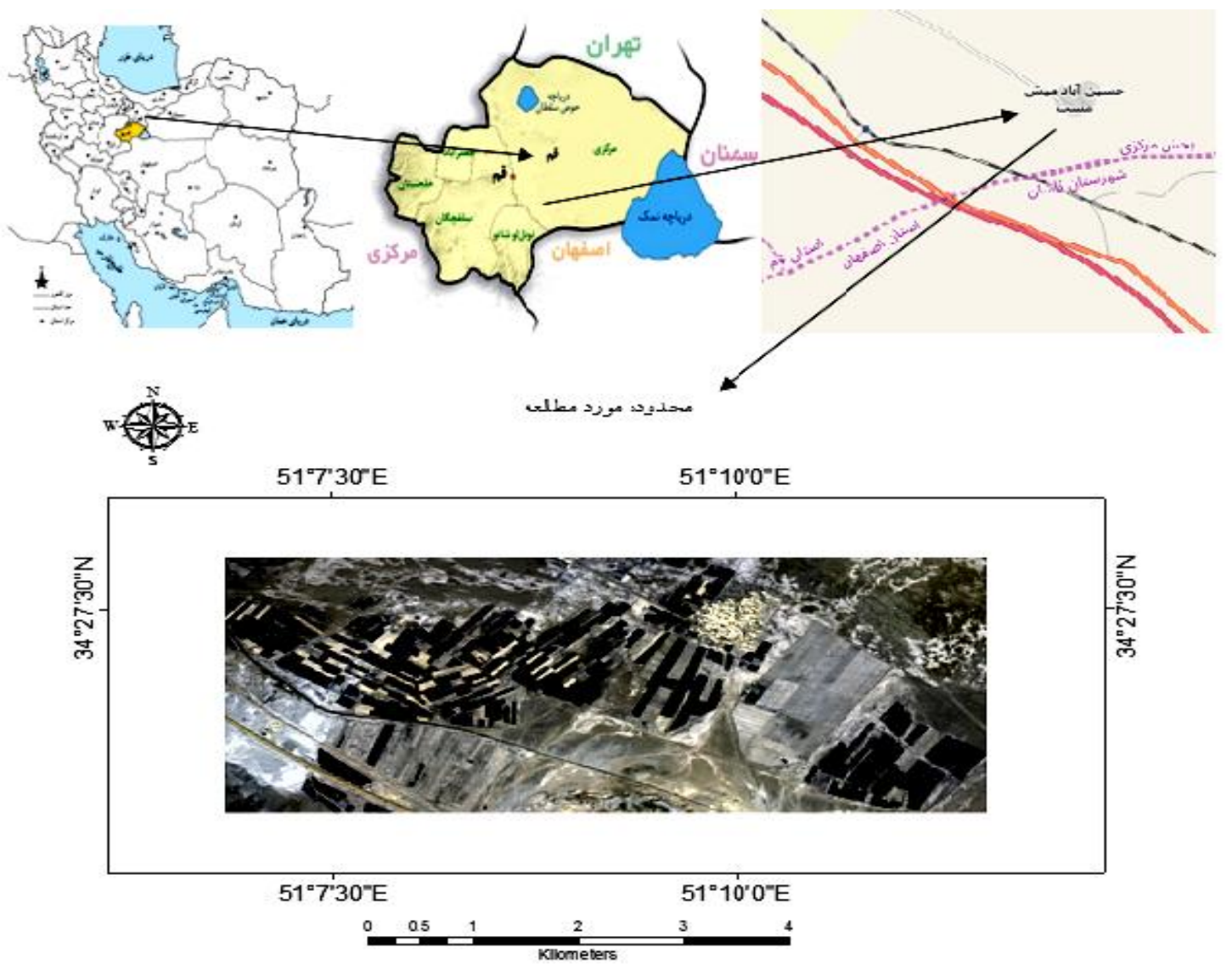

شكل ا. موقعيت منطقه مورد مطالعه

زمينى شامل اطلاعات مربوط به مراحل فنولوزيكى و تقويم زراعى

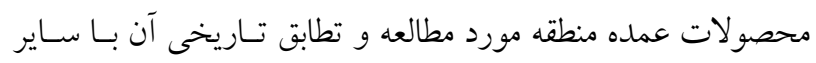

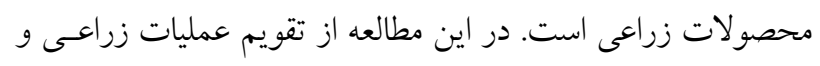

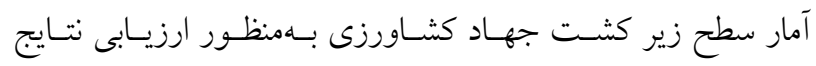

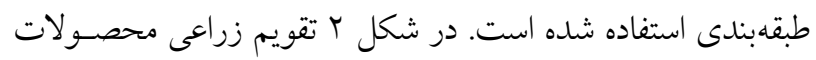

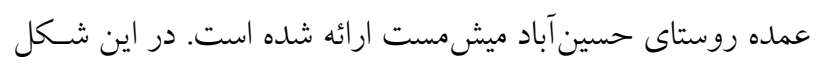

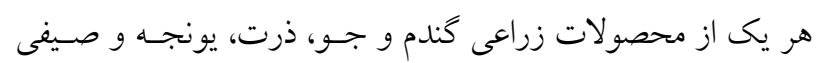
جات بهعنوان كلاسهاى اصلى درنظر كرفته شدهاند.

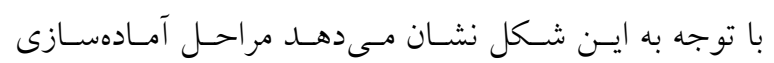

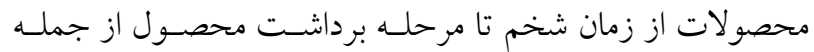

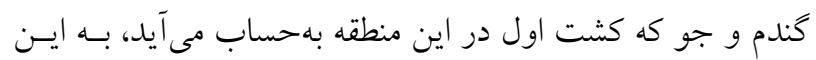

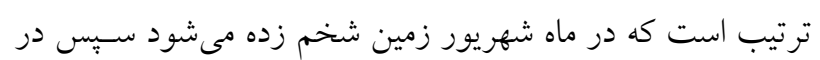
ماه مهر عمل كشت اين محصول انجام مىشود و بعد از V-9 مـاه

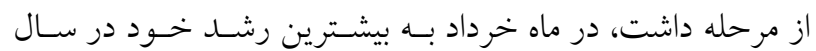

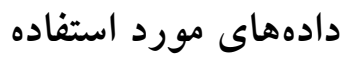

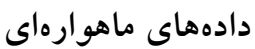
در اين تحقيق دادههاى ماهوارهاى شامل تصـاوير سـرى زمـانى

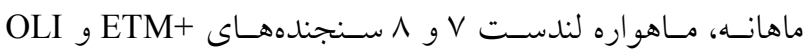

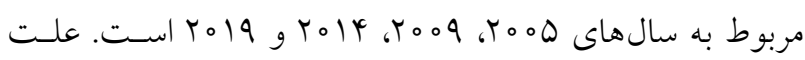
انتخاب تصاوير ماهواره لندست، قدرت تفكيك زمانى و و مكـانى

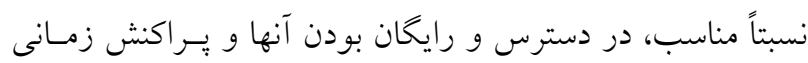

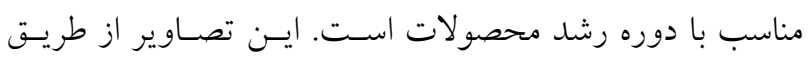
سايت http://earthexplorer.usgs.gov دانلود شده است.

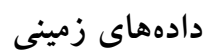
دادههاى زمينسى بــهنظـور ارزيـابى و اعتبارسـنجى نتسايج، در كنـار

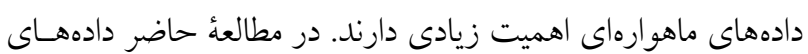




\begin{tabular}{|c|c|c|c|c|c|c|c|c|c|c|c|c|}
\hline \multirow[t]{2}{*}{ آذر } & \multirow[t]{2}{*}{ آبان } & \multirow[t]{2}{*}{ تهر } & \multirow[t]{2}{*}{ ثنهرئور } & \multirow[t]{2}{*}{ شرداد } & \multirow[t]{2}{*}{ ثير } & \multirow[t]{2}{*}{ - خرداد } & \multirow[t]{2}{*}{ اردييهشت } & \multirow[t]{2}{*}{ فروردين } & \multirow[t]{2}{*}{ اعف:د } & \multirow{2}{*}{ بهمن } & \multirow[t]{2}{*}{ دى } & مامهاي ع.ال \\
\hline & & & & & & & & & & & & הتحصول \\
\hline & & & & & & & & & & & & \multirow{3}{*}{ كثندمجوت } \\
\hline & & & & & & & & & & & & \\
\hline & & & & & & & & & & & & \\
\hline & & & & & & & & & & & & \\
\hline & & & & & & & & & & & & \multirow[t]{4}{*}{ ذرت } \\
\hline & & & & & & & & & & & & \\
\hline & & & & & & & & & & & & \\
\hline & 드. & & & & & & & & & & & \\
\hline & & & & & & & & & & & & \multirow[t]{4}{*}{ ئونجه } \\
\hline & & 1 & & & & & & & & & & \\
\hline & & & & & & & & & & & & \\
\hline & & & & & & & & & & & & \\
\hline & & & & & & & & & - & & & \multirow[t]{4}{*}{ صيفىجات } \\
\hline & & & & & & & & & & & & \\
\hline & & & & & & & & & & & & \\
\hline & & & & & & & & & & & & \\
\hline
\end{tabular}

\begin{tabular}{|l|l|ll|l|}
\hline داثخت & & & \\
\hline
\end{tabular}

\section{شكل r. تقويم زراعى محصولات عمده منطقه حسين آباد ميشمست}

محسوس فنولوزيك بين گونـهـــا وجـود داشـته باشـد، تفكيـى كونهها مطلوب تر خواهد بود. بنابراين در اين تحقيق براى استفاده از سرى زمانى تصاوير ماهوارهاى و تعيين دامنه زمانى مناسب بـهـ

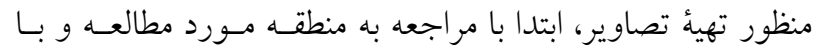

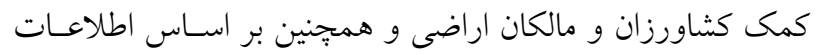

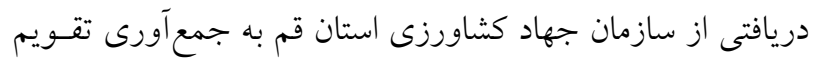

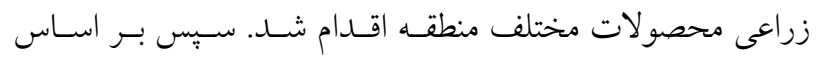

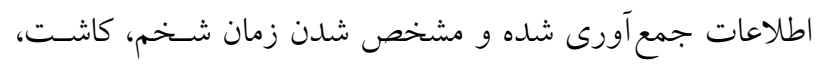

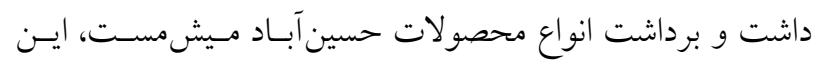

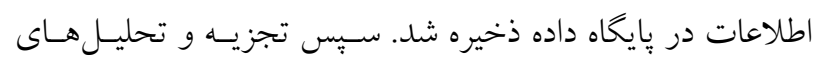

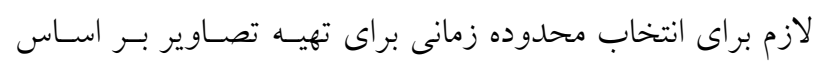

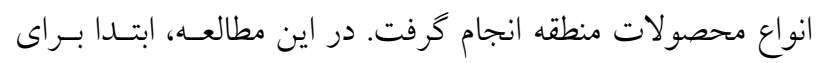

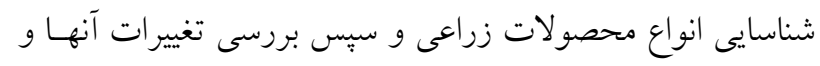

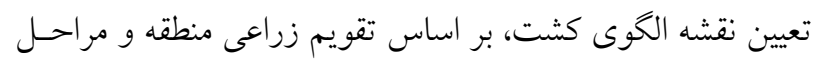

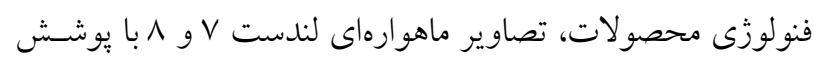

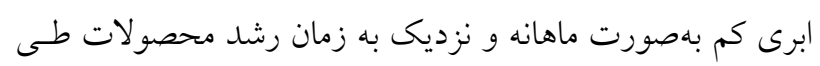

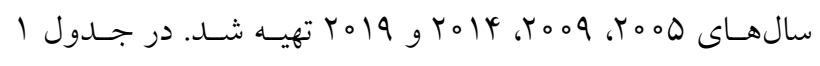

مىرسد. بنابر اين محصول گندم و جو در اين مــاه آمـاده برداشـت

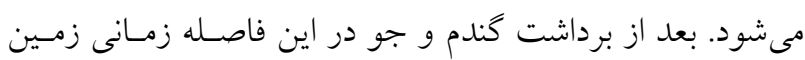

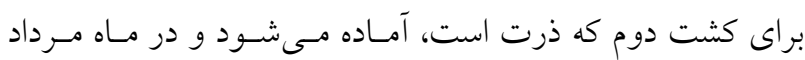

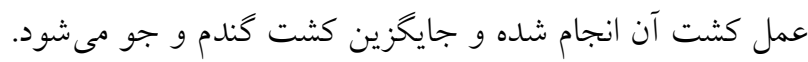
دوره رشد اين محصول سه ماه (90 روز) است كه در اوايل آبـان

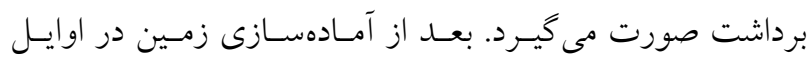

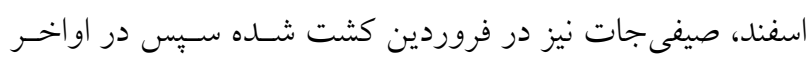

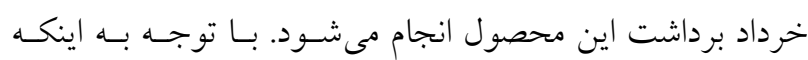

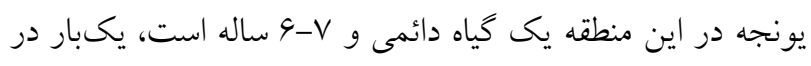

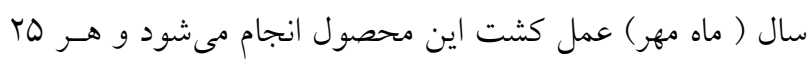

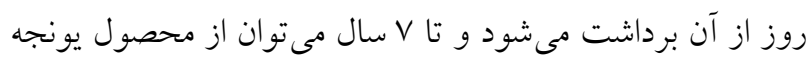

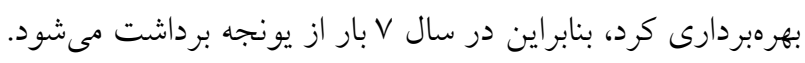

\section{انتخاب زمان تصاوير ماهوارهاى} بهدليل وجود محصولات زراعى متنوع با زمان كاشت و برداشـت مانت

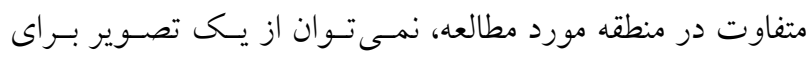

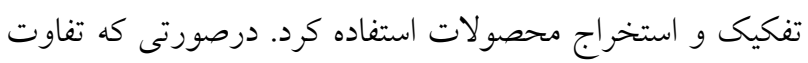


جدول l. تصاوير ماهوارهاى مورد استفاده از لندست لو ^ سنجنده OLTM+ و OLI

\begin{tabular}{|c|c|c|c|c|}
\hline سال 19019 & سال F Y Y & سال rooq & سال ه॰ ب & شماره \\
\hline $10 / \mu \circ$ & $11 / 4$ & $10 / T V$ & $10 / 19$ & 1 \\
\hline$I T / Y$ & $11 / T Y$ & $11 / 14$ & $11 / 11$ & r \\
\hline $1 / 1$ & $1 / V$ & $1 / 9$ & $1 / 9$ & $r$ \\
\hline $\mid / T 1$ & I/Tr & $T / Y$ & $1 / T Y$ & $r$ \\
\hline T/YY & $r / q$ & $r / 9$ & $\Gamma / \Lambda$ & 0 \\
\hline$\varphi / \Lambda$ & $\Gamma / T \Delta$ & $r / 19$ & $4 / q$ & 4 \\
\hline $0 / 9$ & $4 / 1 。$ & $Q / D$ & $\varphi / T \Delta$ & v \\
\hline$\Delta / r \Delta$ & $0 / 11$ & $9 / 9$ & $D / Y G$ & $\wedge$ \\
\hline $9 / 49$ & $9 / T_{1}$ & $V / V$ & $G / T V$ & 9 \\
\hline$V / T V$ & V/Ir & V/Tr & V/IT & 10 \\
\hline$N / I r$ & $1 / 10$ & $\Lambda / T Q$ & $9 / 9$ & 11 \\
\hline $9 / 10$ & $9 / 1 V$ & $9 / 11$ & $9 / 19$ & Ir \\
\hline
\end{tabular}

يك از آنها در آن واحد بالاترين دقت، سرعت يـردازش و اسـتقلال از دادهاى زمينى را بهصورت يكجا ندارند. بـر همسين اسـاس در

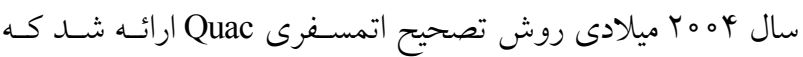
بتواند همه اين موارد را بهصورت يكجا در خود يوشـش دهـد. در اين تحقيق براى تصسحيح اتمسـفرى از الحـوريتم FlAASH بـراى

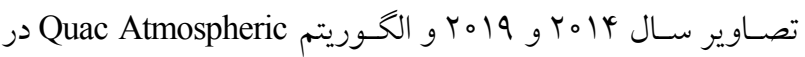

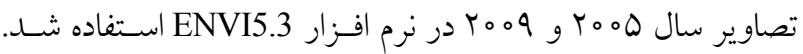
علـت اسـتفاده از روش تصـحيح اتمسـفرى Quac Atmospheric

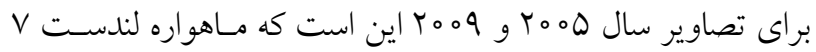

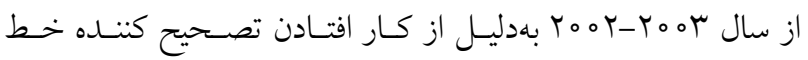
اسكن باعث شــ كـه خطـاى Stripping ايجـاد شـود و برخهى از خطوط اسكن اطلاعاتش از بين برود. براى برطرف كردن اين خطـا بايد تصحيحات راديومتريكى و اتمسفرى برطرف شود و بعد از آن خطاى Gapping برطرف شود. الخوريتم Quac در مقايسه بـا سـاير روشهاى مبتنى بر محاسبات فيزيكى از سـرعت بـالايى برخــوردار است. بررسى هـاى انجـام شــه در ارتبـاط بـا دقت لــ FLAASH و نشان داده كه روش Quac بهصورت تقريبى Qا درصد نتـايج آن با روش FLAASH متفاوت اسـت. بـرخلاف سـاير روشهـاى فيزيكى كه بهشدت از نويزهاى سنجنده تأثير مى يذيرنـد، الخـوريتم
تاريخ هاى مربوط بــه اخـــ تصـاوير مـاهوارهاى مـورد اسـتفاده از لندست Vو ^ سنجنده ارائه شده است.

آمادهازى و يردازش تصاوير ماهوارهاى در مرحله يِيش يردازش، تصاوير ماهوارهاى از نظر راديـومتريكى و اتمسفرى تصحيح مىشوند. براى بهبود كيفيت تصـاوير، افـزيش وضوح و درنتيجه افزايش ميزان اطلاعات قابل استخراج از تصاوير، نيـاز داشـت كـه تصسحيحات راديـومتريكى و اتمسـفرى بــر روى تصاوير صورت بخيـرد. در ايـن تحقيـق تصـحيح راديـومتريكى بــا استفاده از الكوريتم Radiometric Calibration در تصـاوير اسـتفاده شـــ تـاكنون روش هـاى مختلفـى مانـــ Empirical line model و براى تصحيح اتمسفرى تصاوير مـاهوارهاى ارائسه شـده اسـت. در روشهـايى مانـــ Empirical line model بـراى اعمـال تصحيحات نياز به بازتابهاى زمينى است، اين در حالى اسـت كـه روشهاى مبتنى بر مدلهاى انتقال تابشسى ماننــ FLAASH بــدون استفاده از دادهاى زمينى و فقـط بـر اسـاس اطلاعـات موجـود در تصاوير ماهوارهاى فرايند تصحيح انجام مىشـود. هـر كـدام از ايسن روشها از مزيتها و معايب خاص خود برخوردار هستند اما هـيج 
تهيه نقشه الكوى كشت با اعمال آناليز طبقهبندى نظارت شده روى شاخص گياهى در اين مطالعه براى بررسى كارايى هر با سـرى زمـانى تصـاوير لندست براى تهيه نقشه الكَى كشت، از تركيـب بانــى تصـاوير

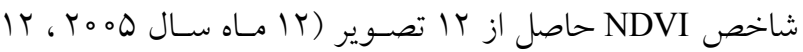

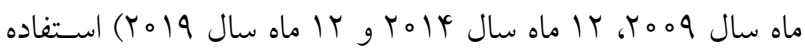

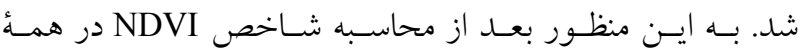
تصاوير، هر يك از تصاوير سرى زمانى سالهاى مورد مطالعه بـهـ

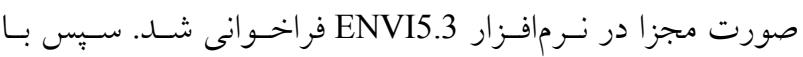

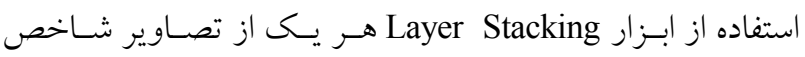

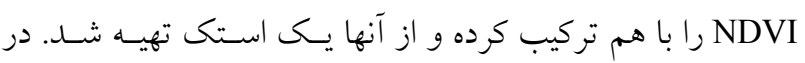

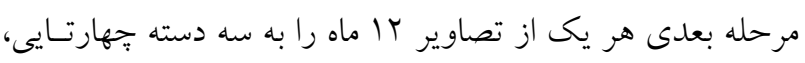

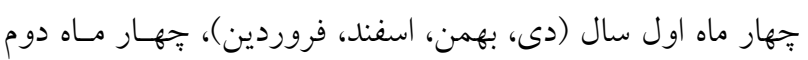

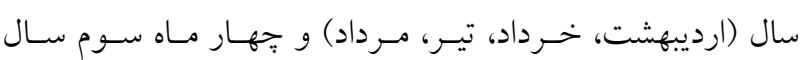

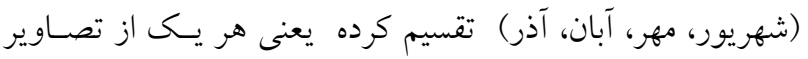

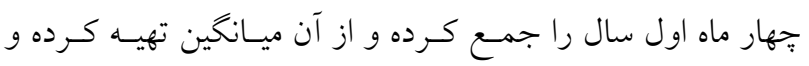
براى تصاوير جهار ماه دوم و سوم سال نيز اين عمل انجام شـــ و

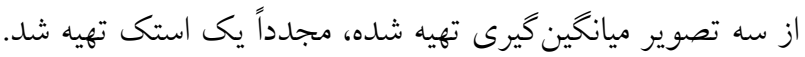
سبس با استفاده از تركيب رنخ اصلى قرمز، سـبز و آبسى (RGB)

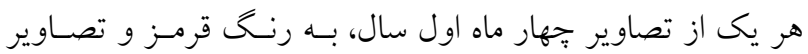

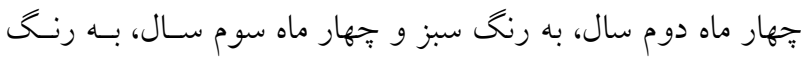

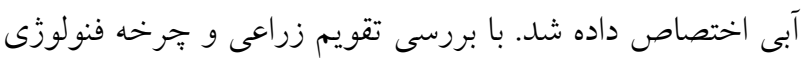

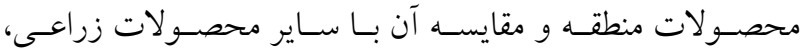

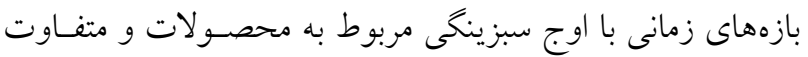

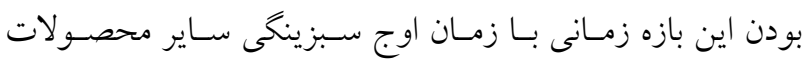
زراعى و نيز با استفاده از ابزار Spectral Profile بـا كليـى كـردن

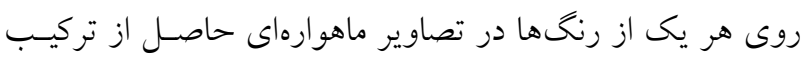

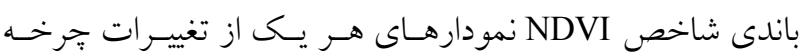

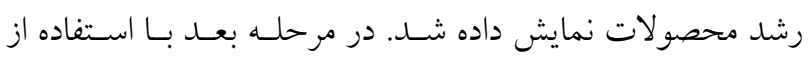

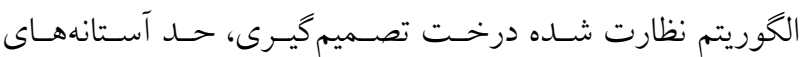
شاخص NDVI متناسب با انواع محصولات زراعى روى تصـاوير

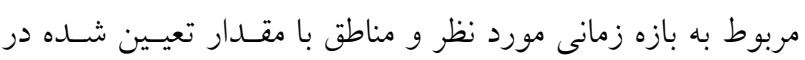

بuac بهورت مستقل از اعوجاجات سـنجنده فراينـد تصسحيح را

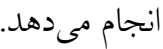

\section{NDVI شاخص گياهى}

شاخص هاى كياهى از يركاربردترين نمونههاى محاسـبات بانــى

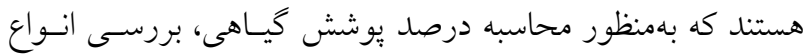

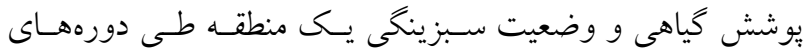
مختلف بهكار مسرود. شـاخص كيـاهى (NDVI) معـروفتـرين، ساده ترين و كاربردى تـرين شـاخصهــاى گيـاهى شـناخته شــده هستند. در طول زمان تغييرات مشاهده شده در NDVI بيان كننده

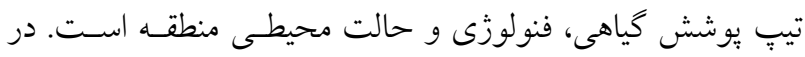

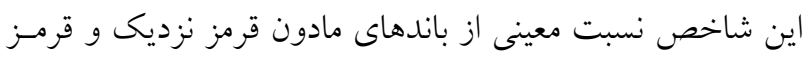
براى نقشههاى بوشش گياهى و بررسى شرايط آنها مورد استفاده

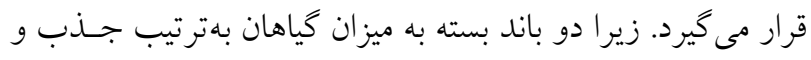

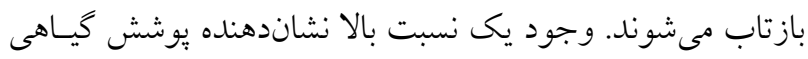

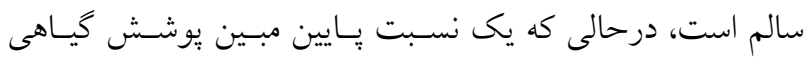
ناسالم و دجـار اسـترس، يـا بــدون يوشـش كيـاهى اسـت (IV).

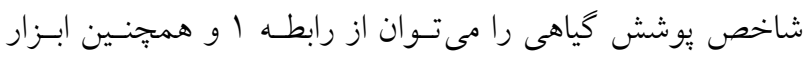
Spectral Indices روش نتيجــه يكســانى دارد. در تحقيـق حاضــر بعـــ از انجــام تصحيحات راديومتريك و اتمسفرى شاخص NDVI با استفاده از ابزار Spectral Indices در هر تصوير بهدست آمد: NDVI=(NIR-RED)/ (NIR+RED)

در ايسـن رابطـه، NIR و RED بـــترتيــب بازتابنـدكى طيفـى

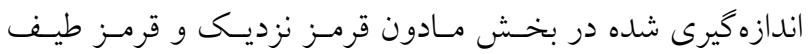
الكترومغناطيس است. مقادير نرمال در ايـن شـاخص داراى قـــر

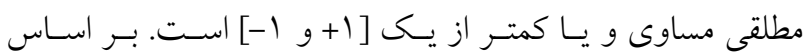

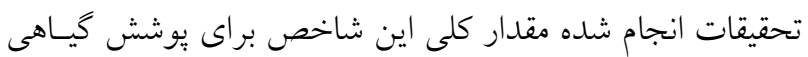

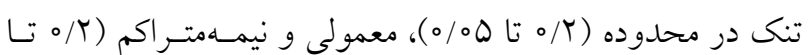

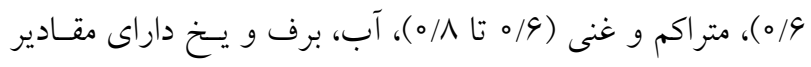

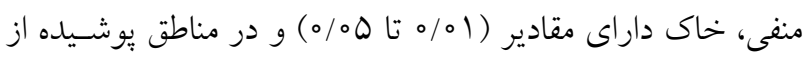
ابر تقريباً برابر با صفر است (V) 
تهيه شد و هر يكى از مساحت زير كشت محصولات به كمـى

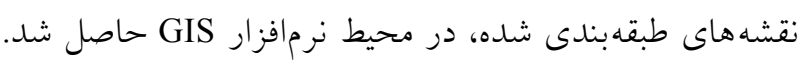

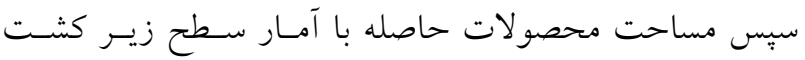

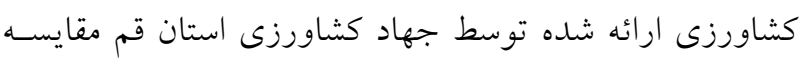

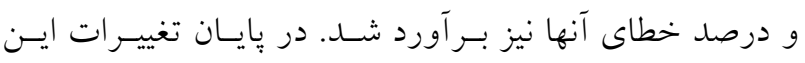

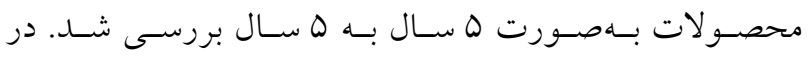

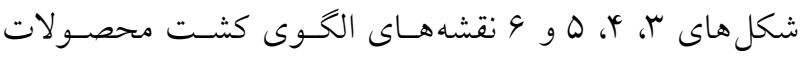

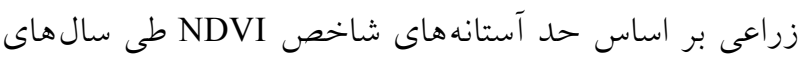
مطالعاتى ارائه شده است.

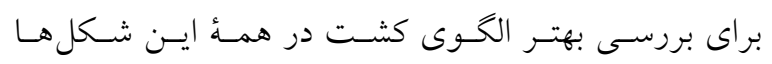

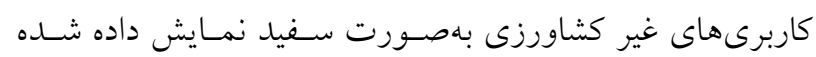

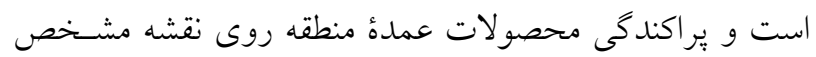

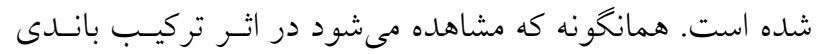

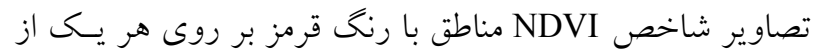

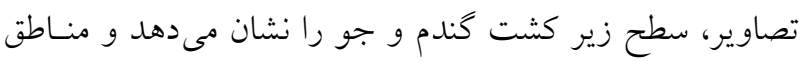

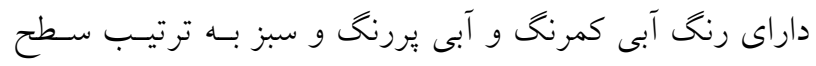
زير كشت يونجه، ذرت و صيفى جات را نشان مى دهد كه دليسل

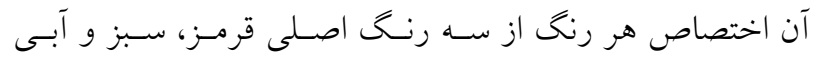
(RGB)

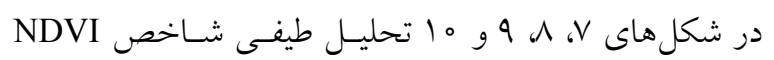

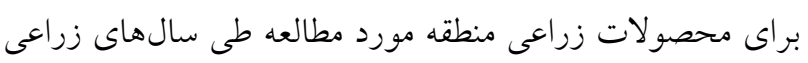

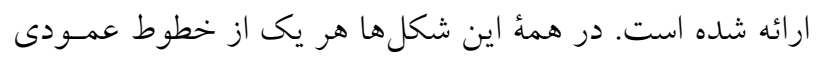

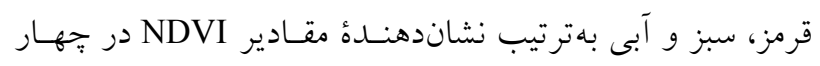

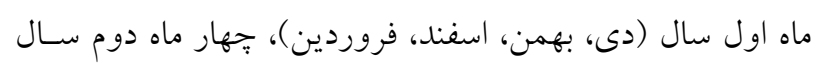

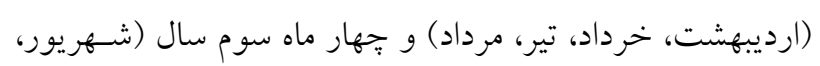

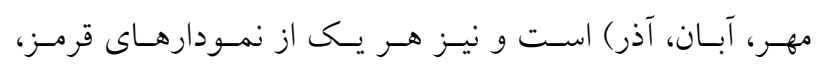

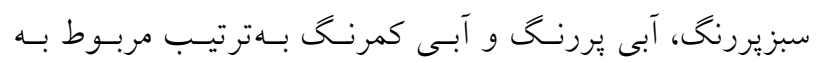

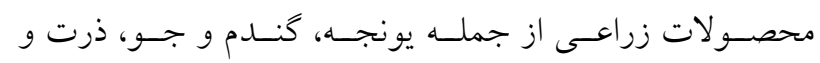
صيفى جات هستند. همانطور كه در همأ اين شـكل هـا نمـودار

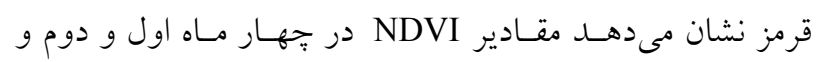

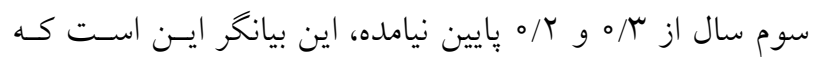

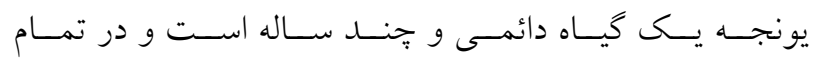

اين شاخص ها شناسايى و تفكيك شد، و نقشه الكوى كثـت بــه

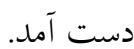

بررسى تغييرات 10 ساله با استفاده از نقشه طبقهبنـدى شـده بر اساس شاخص يوشش گياهى روش هاى مختلفى براى بررسى تغييرات وجـو دود دارد و فرضسيه

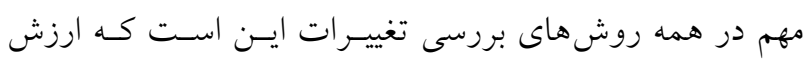

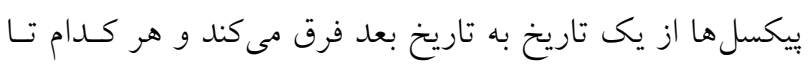

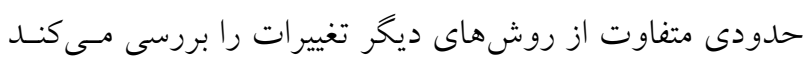

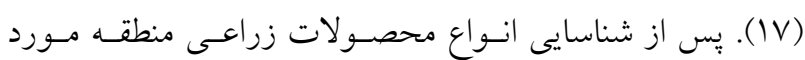

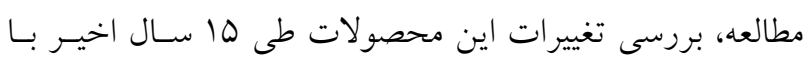

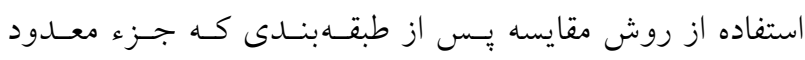

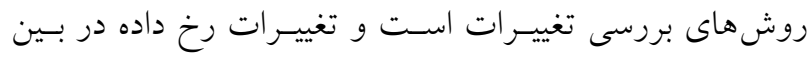

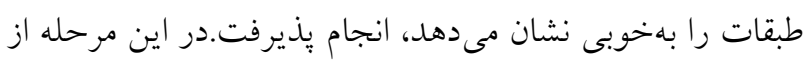

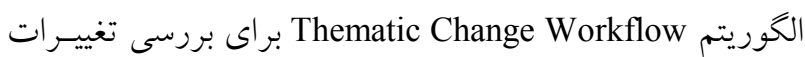
محصولات زراعى استفاده شد.

\section{نتايج و بحث}

NDVI در اين يزوهش يس از انجام تصحيحات لازم، شاخص

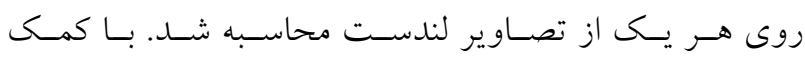

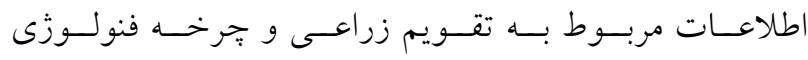

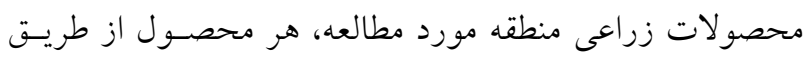

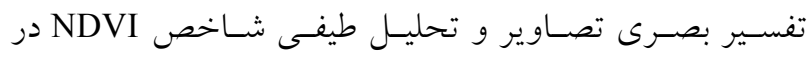

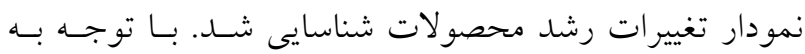
اينكه هر محصول در جهار ماه اول و دوم و سوم سـال داراى

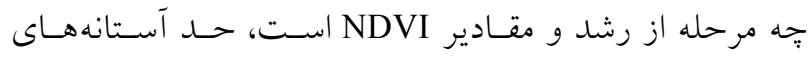
شاخص NDVI متناسب با نوع محصول زراعى از جمله كندم

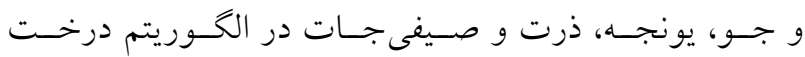

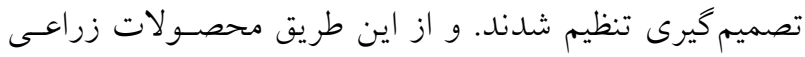

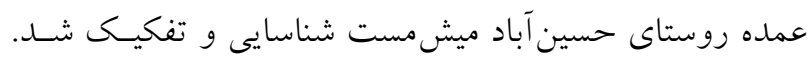

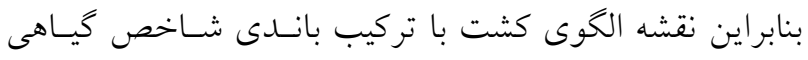

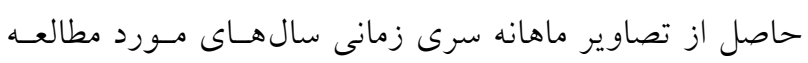




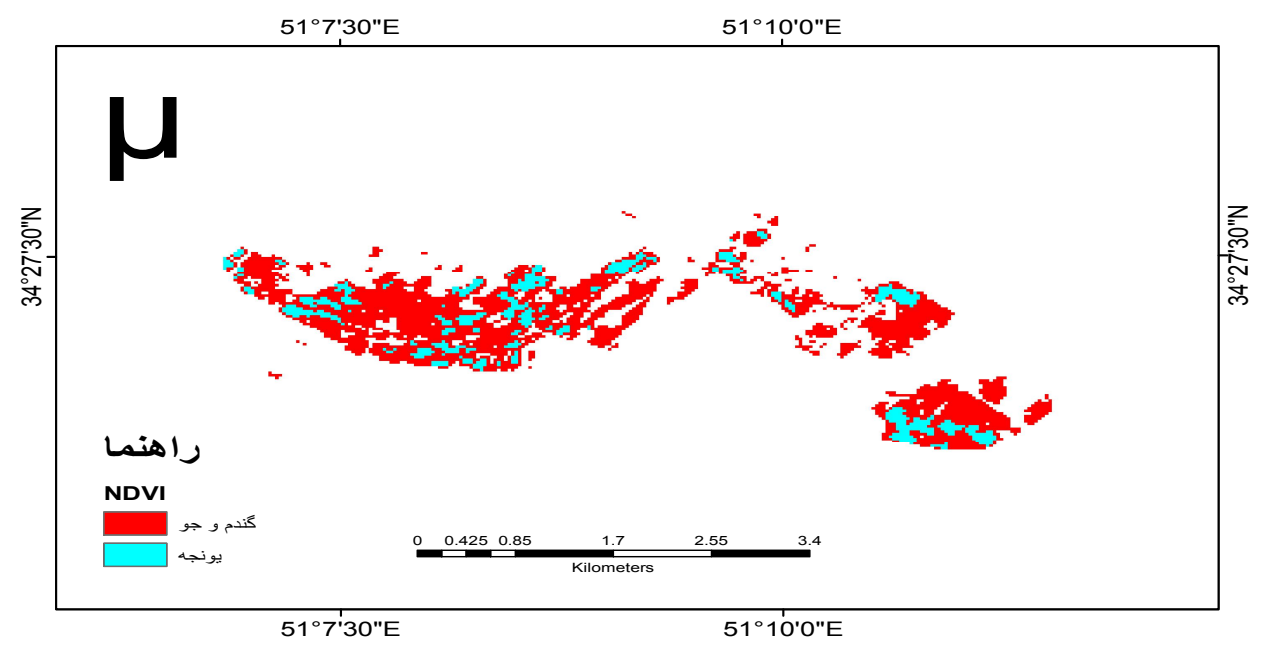

شكل r. نقشه الكوى كشت محصولات زراعى بر اساس حد آستانهاى شاخص NDVI سال هـYo (رنكى در نسخه الكترونيكى)

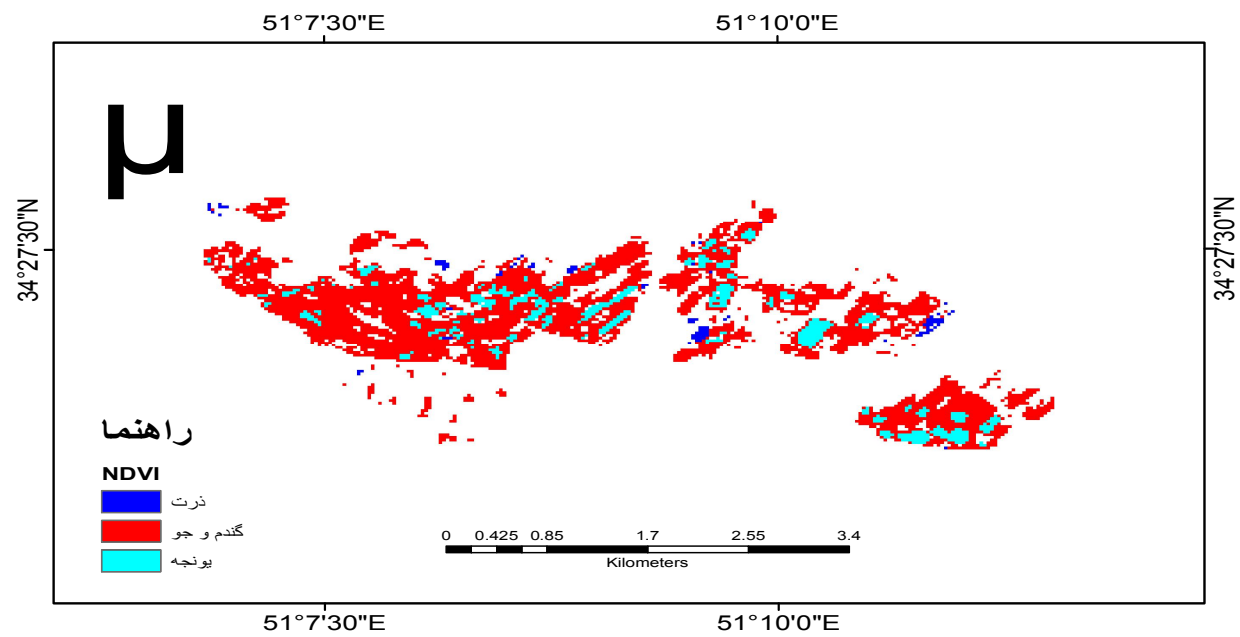

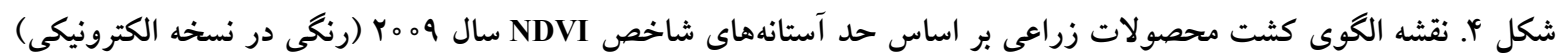

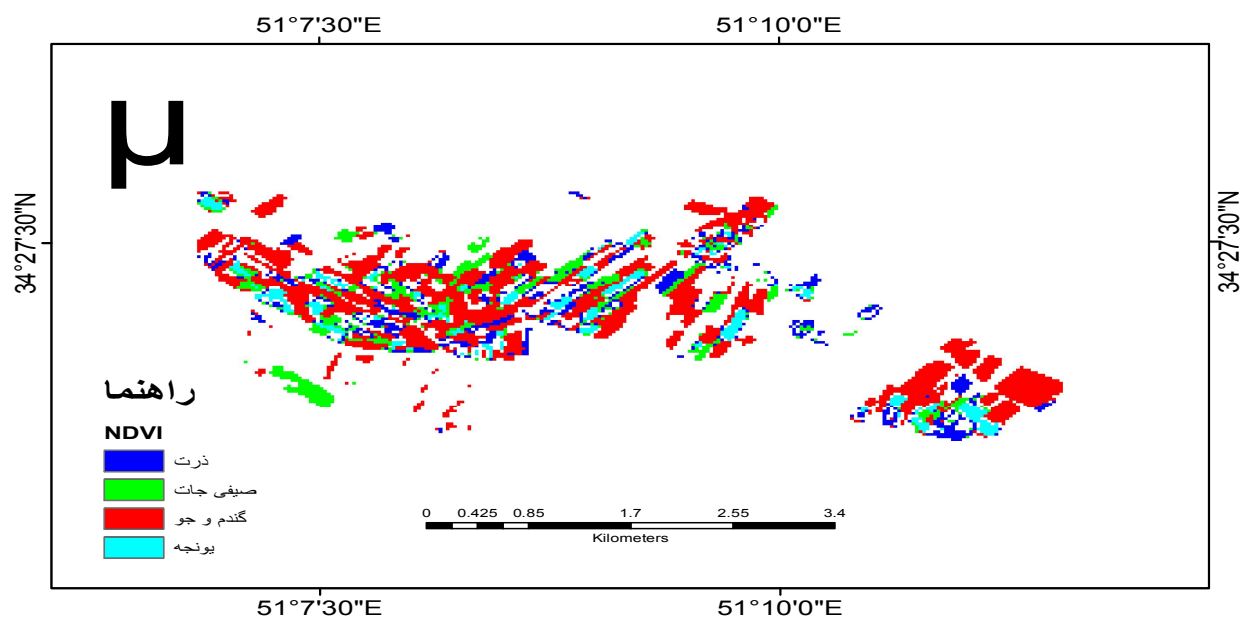

شكل ه. نقشه الكوى كثت محصولات زراعى بر اساس حد آستانهاى شاخص NDVI سال Y.|F (رنكى در نسخه الكترونيكى) 


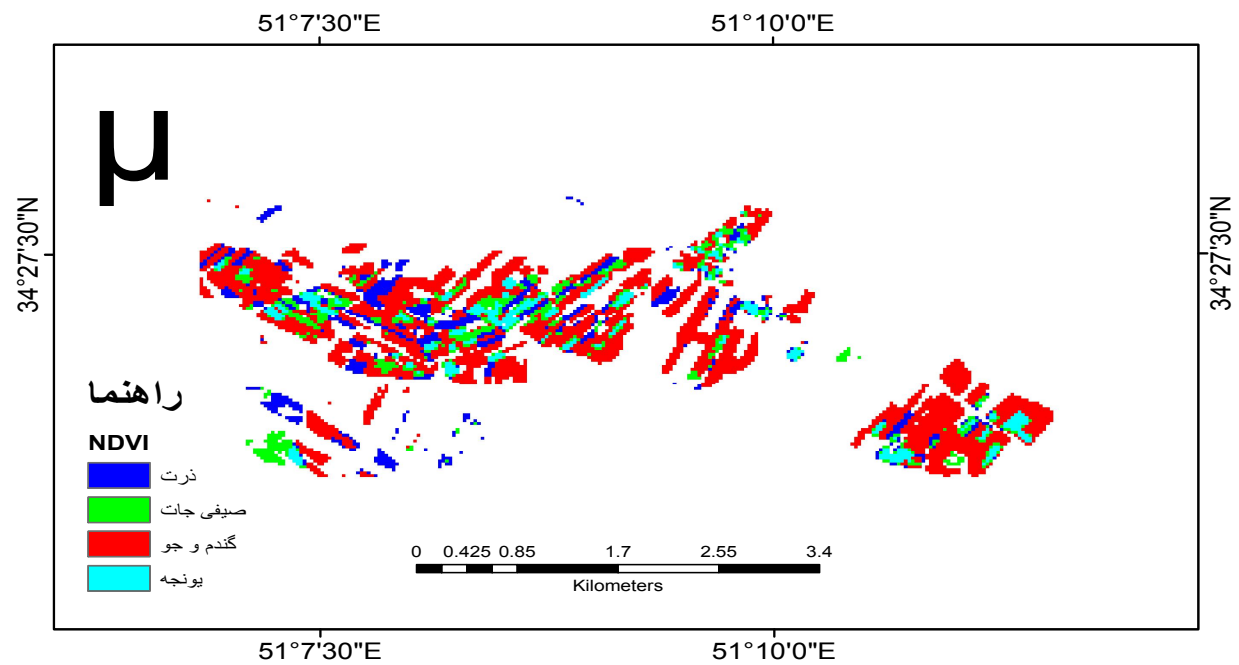

شكل 9. نقشه الكوى كشت محصولات زراعى بر اساس حد آستانهاى شاخص NDVI سال 19 Y (رنخى در نسخه الكترونيكى)

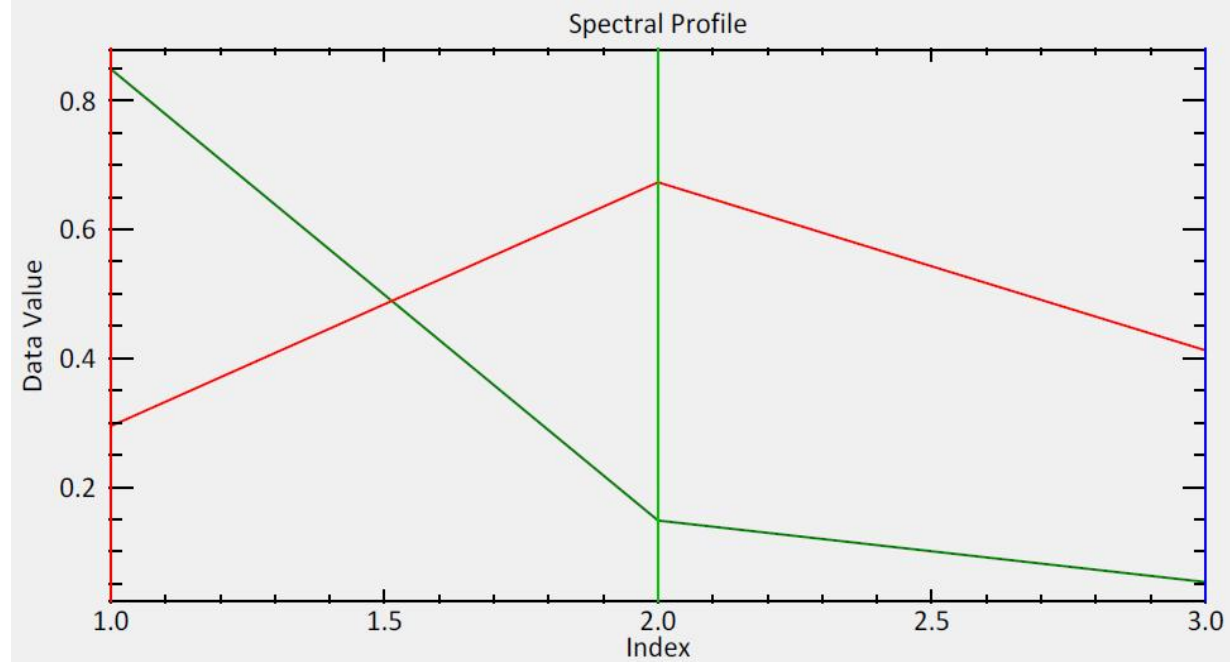

شكل V. تحليل طيفى شاخص NDVI براى يونجه (قرمز) و گندم و جو (سبز بررنح) در سال هo Y (رنكى در نسخه الكترونيكى)

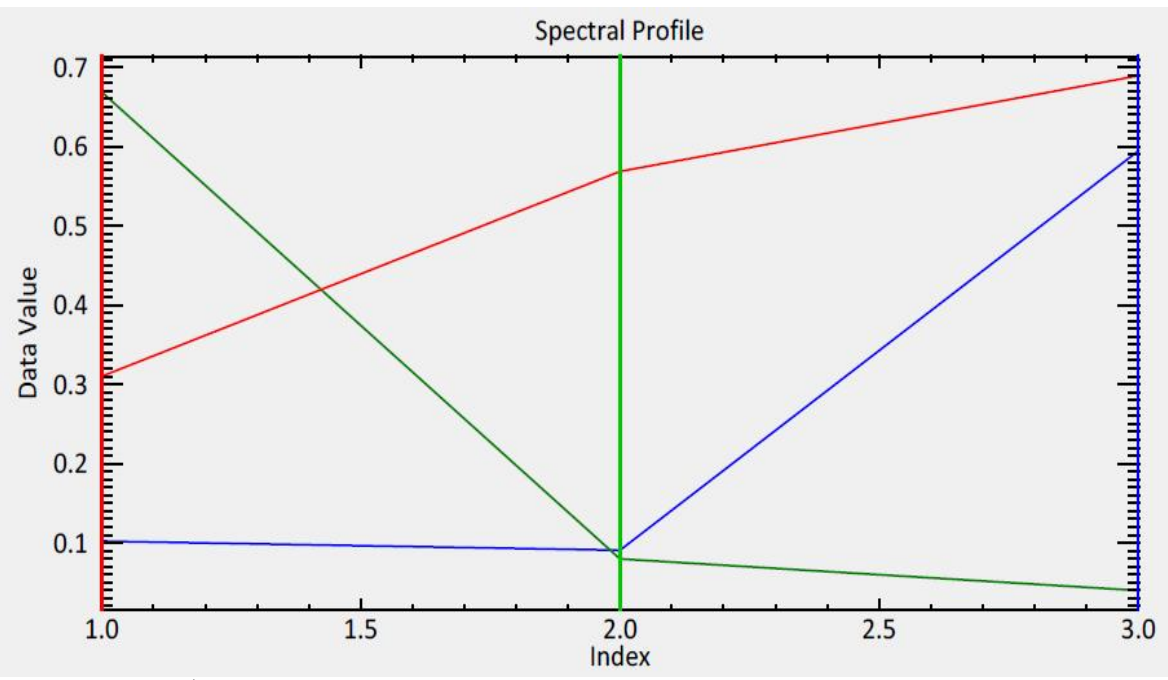

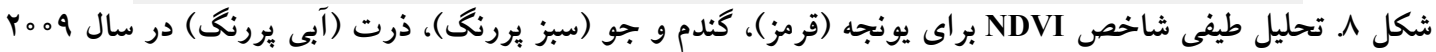

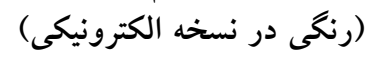




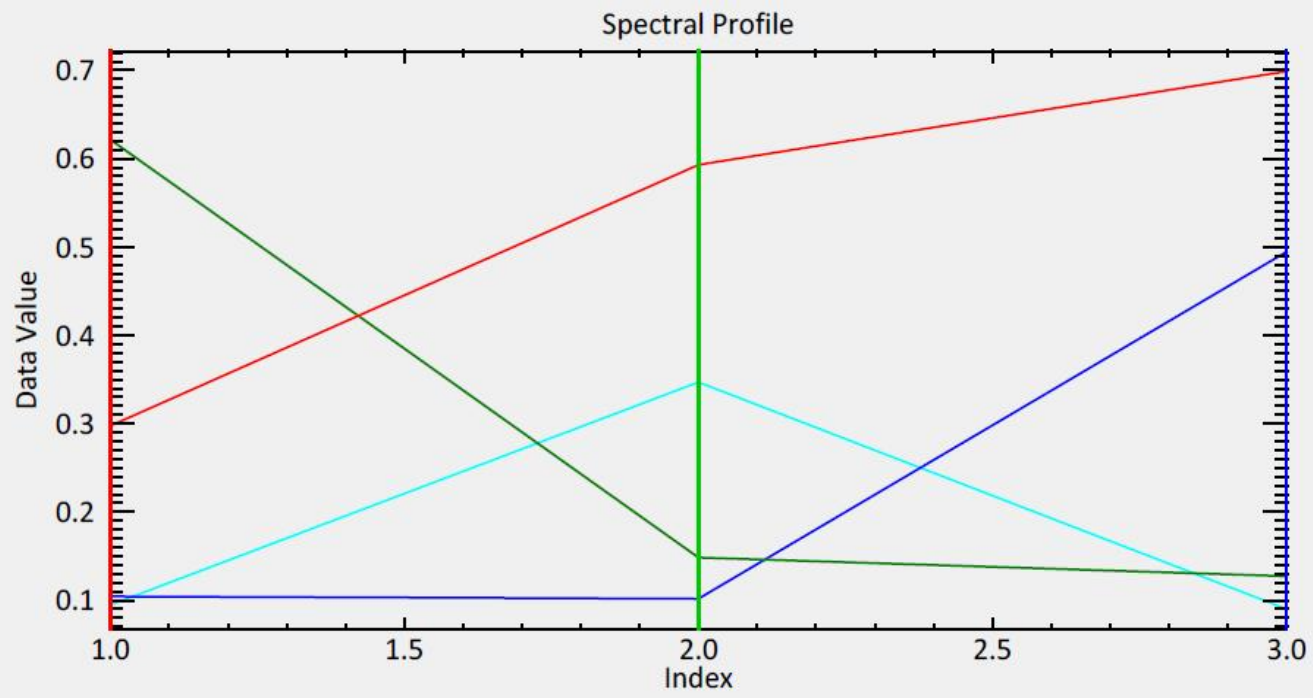

شكل 9.

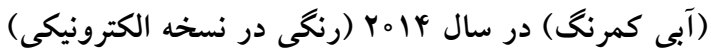

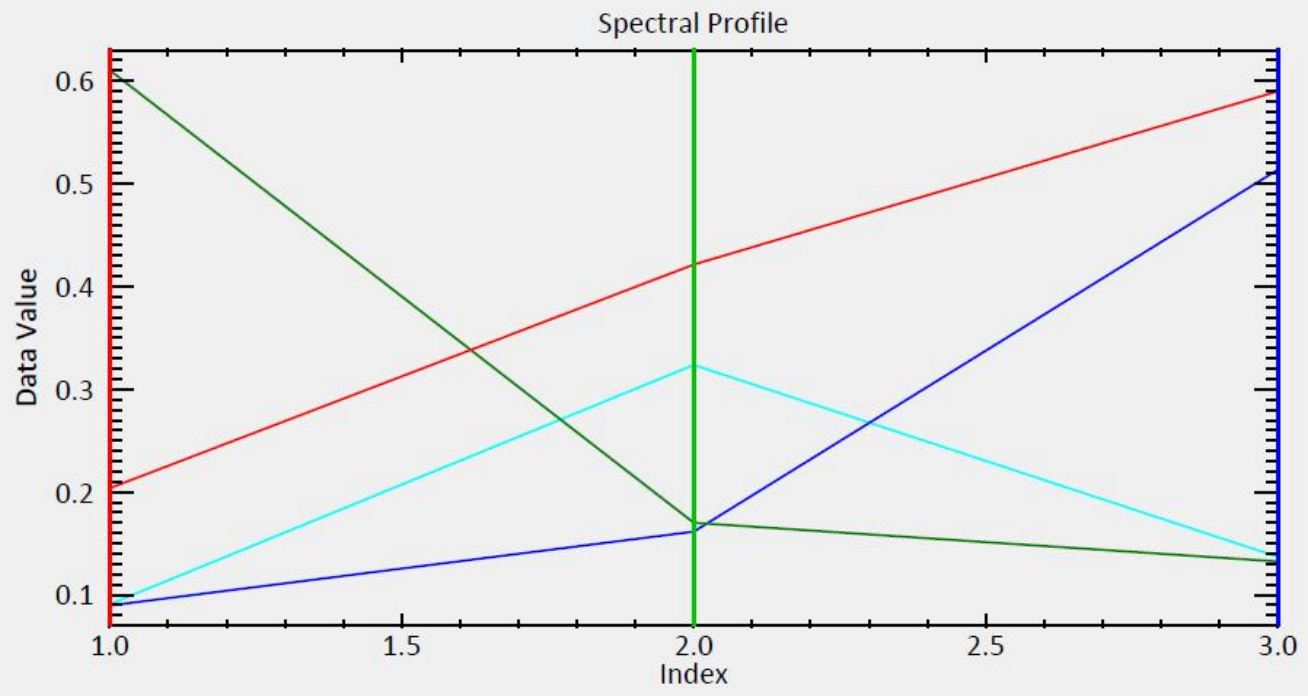

شكل ه 1. تحليل طيفى شاخص NDVI براى يونجه (قرمز)، گندم و جو (سبز يررنگ)، ذرت (آبى يررنگ)، صيفى جات

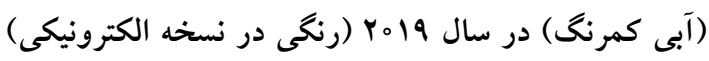

مى دهد كه در جهار ماه سوم سال ذرت به حسداكثر رشـــ خـود

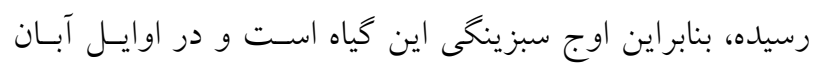

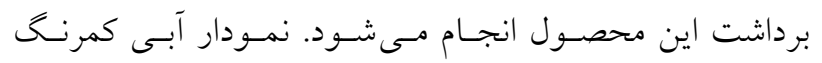

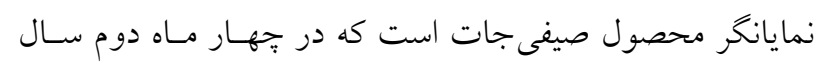

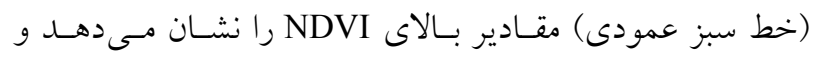

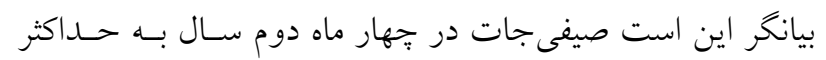
رشد خود رسيده و در اواخر ماه خرداد برداشت مىشود.
طول سال داراى بوشش گياهى است. با توجه بـهـ نمـودار سـبز

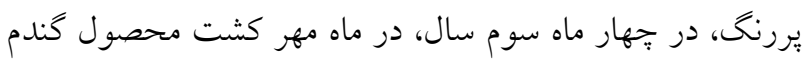

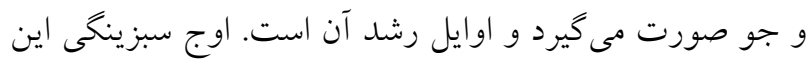

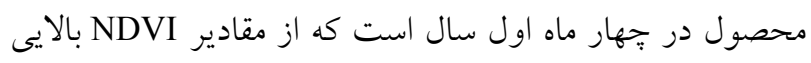

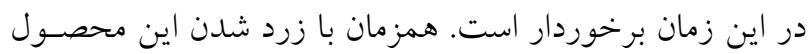

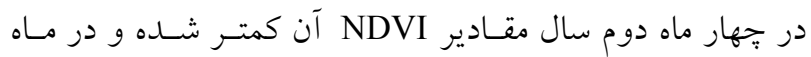

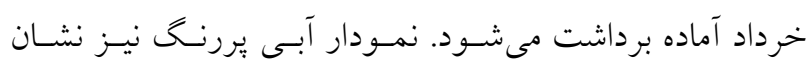


جدول Y. سطح زير كشت بر اساس مقادير شاخص NDVI و آمار جهاد كشاورزى در سال ه० Y

\begin{tabular}{|c|c|c|c|c|}
\hline ميزان خطا (درصد) & آمار جهاد كشاورزى (هكتار) & مساحت (درصد) & مساحت (هكتار) & وع محصول \\
\hline$-9 / 1$ & 1。 & $1 N / 4 V$ & $V Q / \circ G$ & يونجه \\
\hline$-\mid V / 1$ & Y०。 & $\Lambda 1 / \Delta T$ & 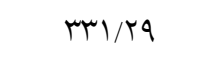 & كندم و جو \\
\hline$-10 / \mu$ & $\uparrow \wedge 。$ & 100 & $r \circ \varphi / \pi \Delta$ & كل \\
\hline
\end{tabular}

جدول r. سطح زير كشت بر اساس شاخص NDVI و آمار جهاد كشاورزى در سال Yo0

\begin{tabular}{|c|c|c|c|c|}
\hline ميزان خطا (درصد) & آمار جهاد كشاورزى (هكتار) & مساحت (درصد) & مساحت (هكتار) & نوع محصول \\
\hline$-9 / 9$ & $V_{0}$ & Ir/4T & $q \mu / T V$ & يونجه \\
\hline$-0 / 0$ & Yoo & $\Lambda \uparrow / 4 \Delta$ & $r q v / 91$ & كندم و جو \\
\hline$-0 / 1$ & 10 & $r / 11$ & $9 / 99$ & ذرت \\
\hline$-1 / 1$ & $\psi \wedge 。$ & 100 & $F V I / Y Y$ & كل \\
\hline
\end{tabular}

جدول fا. سطح زير كشت بر اساس شاخص NDVI و آمار جهاد كشاورزى در سال Yolf

\begin{tabular}{|c|c|c|c|c|}
\hline ميزان خطا (درصد) & آمار جهاد كشاورزى (هكتار) & مساحت (درصد) & مساحت (هكتار) & نوع محصول \\
\hline$-0 / 4$ & YQ & $9 / 0 \circ$ & KY/AT & يونجه \\
\hline$-4 / 9$ & $r q 0$ & $\Delta N / \mu^{\alpha}$ & $T V Q / D \Lambda$ & كندم و جو \\
\hline$+11 / 4$ & V。 & $19 / 04^{\circ}$ & VN/Or & ذرت \\
\hline$-Y / T^{c}$ & VQ & $10 / 01$ & $V \Psi / I V$ & صيفىجات \\
\hline$-1 / V$ & ४人。 & 100 & $4 \times 1 / 9$ & كل \\
\hline
\end{tabular}

همان كونه كه مشاهده شد رفتار طيفى هر يك از محصـولات در جدولهاى r، ا، باو ه سطح زير كشت بـر اسـاس مقـادير زراعى در طول دوره رشـد متفـاوت اسـت و در يـك زمـان شهـاخص NDVI و آمـار جهـاد كشـاورزى برحسـب هكتـار و خاص نمى توان تمامى محصولات را در وضعيت يكسـان از درصد طى سالهاى مطالعاتى ارائه شده است. دوره رشد، در تصوير مشاهده كرد و زمان اوج سبزينكى هر در جدول r طبق نتايج بهدست آمده از حد آستانهاى شـاخص

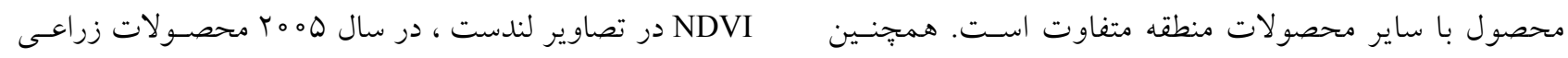
نتايج همهٔ اين شكل هـا نشـان داد كـه زمـان اوج سـبزينكى در اين منطقه شامل يونجه و كندم و جو بوده و اين محصولات

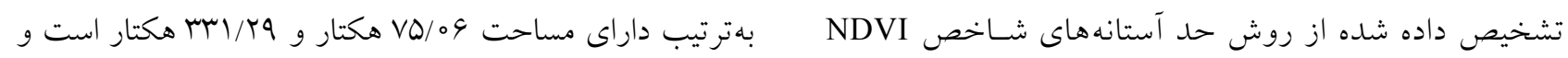

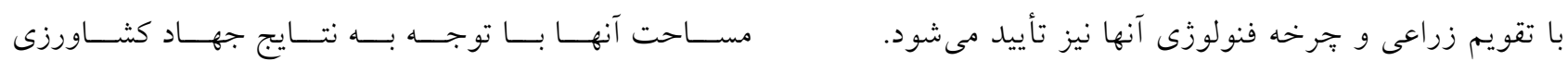


جدول ه. سطح زير كشت بر اساس شاخص NDVI و آمار جهاد كشاورزى در سال 19 Y

\begin{tabular}{|c|c|c|c|c|}
\hline ميزان خطا (درصد) & آمار جهاد كشاورزى (هكتار) & مساحت (درصد) & مساحت (هكتار) & نوع محصول \\
\hline$-11 / 9$ & Q. & $1 / 90$ & $4 y / 19$ & يونجه \\
\hline$+0 / 04$ & M。 & $G Y / 4 \wedge$ & $M \circ / l y$ & كندم و جو \\
\hline$+1 / 4$ & VQ & $10 / r+1$ & $\mathrm{~V} 9 / \circ \Delta$ & 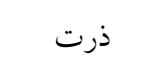 \\
\hline$-1 V / 0$ & $\Lambda \circ$ & $1 r / r q$ & $90 / 9 V$ & صيفى جات \\
\hline -r/9 & 010 & 100 & $4 a \& / \pi \Delta$ & كل \\
\hline
\end{tabular}

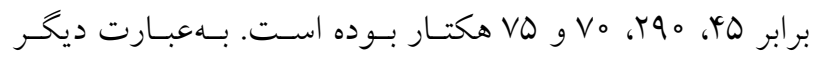

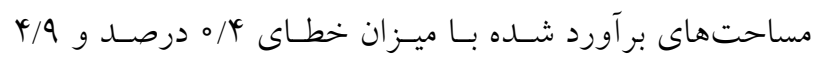

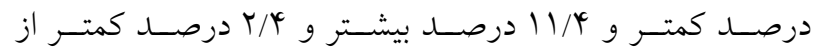
مساحتهاى موجود است.

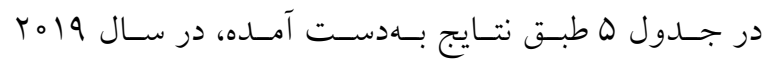

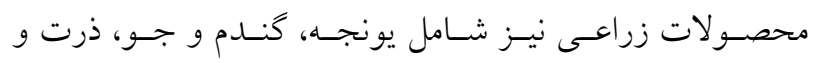

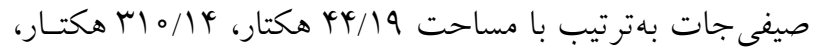

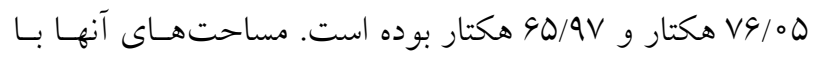

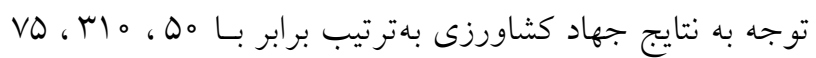
و م1 هكتار بوده است. بنابراين مساحت هاى محاسـبه شــده بـا

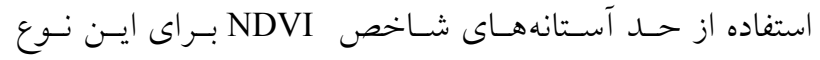

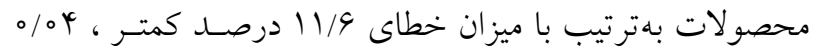
درصد و أ| درصد بيشتر و V/0 درصد كمتر از مساحتهـاى موجود است.

\section{نتيجه كيرى}

نتـايج شناسـايى و تفكيـك محصـولات زراعى عمــده منطقـهـ حسين آباد ميشمست و بررسى تغييرات سطح زيسر كشـت آنهـا

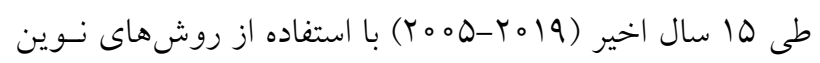

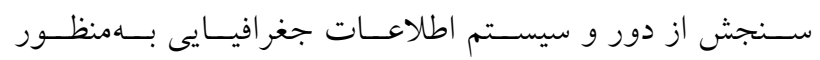

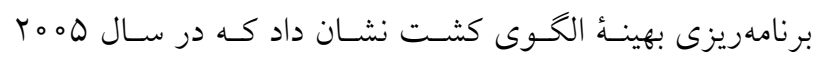
محصولات زراعى اين منطقه شامل يونجسه، كنــدم و جـو بـوده

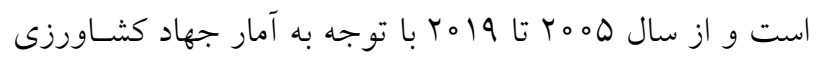

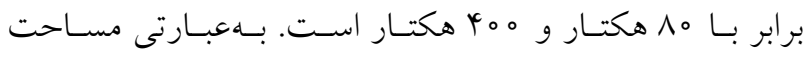

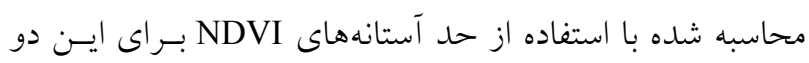

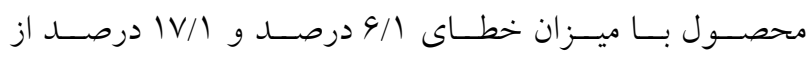
مساحتهاى موجود كمتر است.

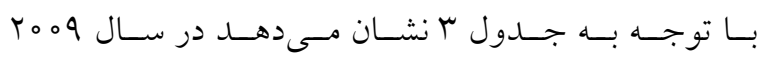
محصولات زراعى شامل يونجه، گندم و جو و ذرت بوده اسـت

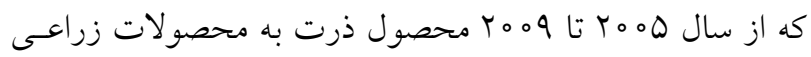
اين منطقه اضافه شده است. مساحت يونجه، كُندم و جـو، ذرت

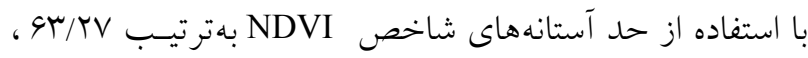
9V/91 و 9/99 هكتــار بــوده اسـت و مســاحتهــاى ايسن محصولات در اين سال زراعى با توجه به نتايج جهاد كشاورزى

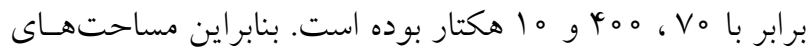
محاسبه شده براى اين سه محصول به ترتيب بـا ميـزان خطـاى 9/9 ، 0/0 و / / درصد از مساحت جهاد كشاورزى كمتر است.

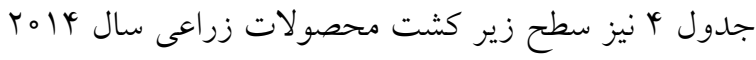

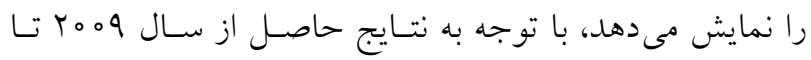

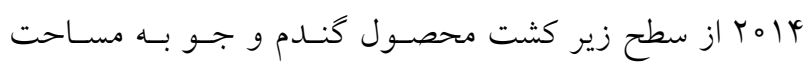
ذرت تبـديل شــده همجنــين در ايسـن سـال صـيفى جــات بـهـ محصولات اين منطقه اضافه شده اسـت. مسـاحت محصـولات زراعسى در ايسـن سـال بــراى يونجــه، گنـــدم و جــو، ذرت و

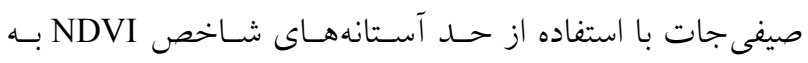
ترتيـــ

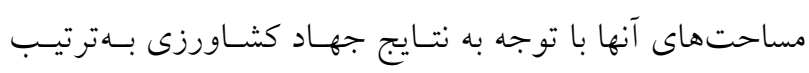


برآورد محصولات زراعى اين منطقه با توجه به جرخه فنولوزى آنها مشخص شد. نتايج تحقيق رياحى و همكــاران (ها) نيـز در

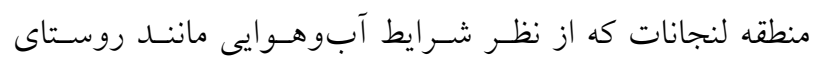
حسين آباد ميش مست، خشك است، كارايى مناسـب شـاخص NDVI تصاوير ماهواره اي لندست بهكمى جرخهـه فنولـوزى و تقـويم زراعى محصولات اين منطقه را نشان داد و اختلاف بسيار كمى ميان نتايج حاصل از اين روش با آمار جهاد كشاورزى مشـاهده شد نتايج تحقيق يورغلام و رحيمزادگـان (11) و فـرزاد مهـر و

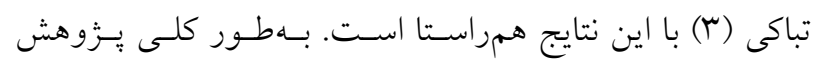
حاضر نشان داد كه تصاوير مـاهوارهاى از قابليـت بـالايى بـراى شناسايى و تفكيك انواع محصولات و بررسى تغييسرات سـطح زير كشت آنها با دقت مناسب در مقياس بالا برخوردار است. از سوى ديخر تصاوير ماهوارهاى مىتواند كاربردهـاى ديخــى در بخش زراعى از جمله ييشبينى و بر آورد خسارت و تسنشهـاى

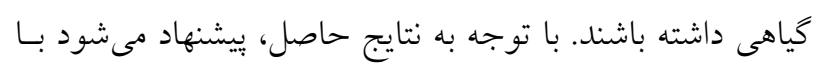
بهكار گيرى روش هاى ديخر مانند ماشين بــردار بشــيبان، شـبكه

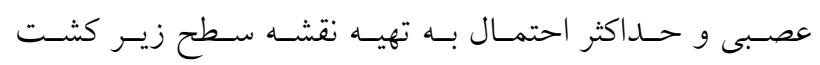
محصولات مختلف با تصاوير ماهوارهاى و سنجندههاى مختلف اقدام شود. همجنين براى تعيين سطح زير كشت محصولات اين منطقه از بيادهسازى ساير شـاخص هـاى كيـاهى از جملـه EVI استفاده شود.
سطح زير كشت يونجه از 01 هكتار به مه هكتار و سـطح زيسر

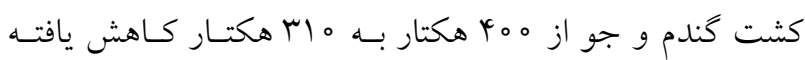
است كه علت كاهش آن عدم يايدارى بـارش در ايـن منطقـهـ و

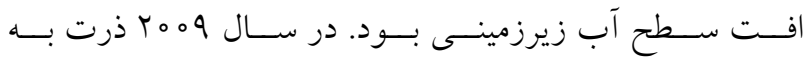
محصولات زراعى اين منطقه اضافه شـد، كـه علـت آن كـمكـم روى آوردن مردم اين منطقه از شغل دامدارى به كشاورزى بود،

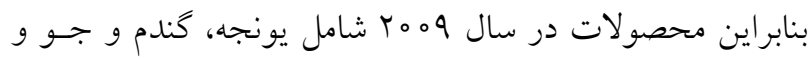

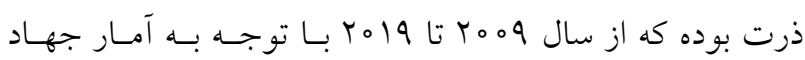
كشاورزى سطح زيسر كشـت ذرت از ه 1 هكتـار بــ VD هكتــار

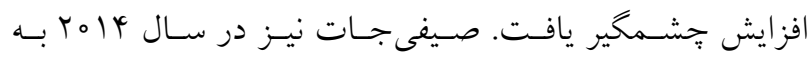
محصولات اين منطقه اضافه شد، درنتيجه محصولات زراعى در

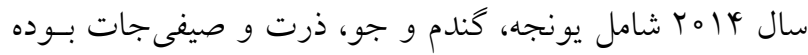

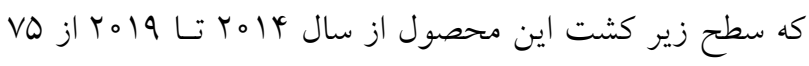
هكتار به م1 هكتـار افـزايش يافت و سـطح زيـر كشـت ايسن محصولات (يونجه، گندم و جو، ذرت و صيفىجـات) در سـال

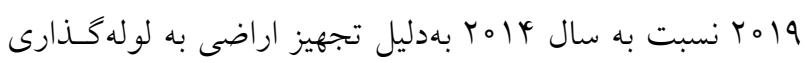
و انتقال آب و بارش مؤثر سال \ه افرايش يافت. در اين تحقيق با توجه به مساحت محصولات زراعى بهدست آمده از شـاخص

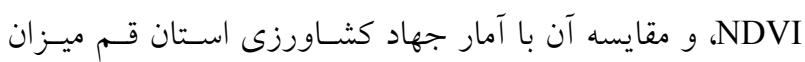
خطاى آنها نيز برآورد شد، كه خطا معنادار نبوده و مساحت هـر يك از محصولات زراعى درصد اختلاف كمى بــا مقــدار آمـار جهاد كشاورزى داشته است. نتايج نشان داد كه حد آسـانههـاى شاخص NDVI، برآورد مناسب و رضايتبخـش از سـطح زيـر

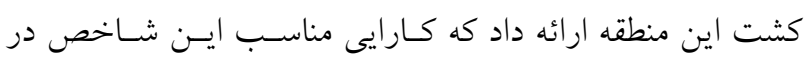

\section{منابع مورد استفاده}

1. Blaschke, T. 2010. Object based image analysis for remote sensing. ISPRS Journal of Photogrammetry and Remote Sensing 65(1): 2-16.

2. Bendini, H., I. D. Sanches, T. S. Korting, L. M. G. Fonseca, A. J. B. Luiz and A. R. Formaggio. 2016. Using Landsat 8 Image Time Series for Crop Mapping in a Region of Crrado, Brazil. The International Archieves of the Photogrammetry, Remote Sensing and Spatial Information Sciences, Volume XLI-B8.

3. Farzadmehr, J. and K. Tabaki Bojestani. 2019. Cabability of landsat 8 satellite image to estimate the area under cultivation of saffron (case study: city of Torbat Heydarih). Journal of Agriculture and Saffron Technology 6(1): 4960. (In Farsi).

4. Kamkar, B., M. Dashti Marvili and H. Kazemi. 2020. Detection of rice and soybean grown fields and their related cultivation area using sentinel 2 satellite images in summer cropping patterns to analyse temporal changes in their 
cultivation area (case study: four watershed basins of Golestan Province). Journal of Water and soil Conservation 26(1): 151-167. (In Farsi).

5. Khodakarami, L. and A. Soffianian. 2013. Application of multi temporal remote sensing for precision farming. Journal of Science and Technology of Agriculture and Natural Resources, Water and Soil Science and Technology 16(59): 215-231. (In Farsi).

6. Kordi, F., S. Hamzeh, S. Atarchi and K. Alavipanah. 2019. Agricultural product classification for optimal water resource management using the data time series of landsat 8. Iranian Journal of Ecohydrology 5(4): 1267-1283. (In Farsi).

7. Kamusoko, C. and M. Aniya. 2007. Land use/cover change and landscape fragmentation analysis in the Bindura District, Zimbabwe. Journal of Land Degradation \& Development 18(2): 221-233.

8. Ke, Y., J. Im, J. Lee, H. Gong and Y. Ryu. 2015. Characteristics of landsat 8 OLI-derived NDVI by comparison with multiple satellite sensors and in-situ observations. Journal of Remote Sensing Environment 164: 298-313.

9. Lu, D. and Q. Weng. 2007. A survey of image classification methods and techniques for improving classification performance. International Journal of Remote Sensing 28(5): 823-870.

10. Otukei, J. and T. Blaschke. 2010. Land cover change assessment using decision trees, support vector machines and maximum likelihood classification algorithms. International Journal of Applied Earth Observation and Geoinformation 12: S27-S31.

11. Pourgholam, M. and M. Rahimzadegan. 2016. Determination of barley cultivation using images landsat 8 satellite. National Conference Civil Engineering and Research Oriented Requirements, Mashhad, Khavaran Higher Education Institute. (In Farsi).

12. Pourgholam, M. and M. Rahimzadegan. 2017. Identification of the area under cultivation of saffron using landsat 8 temporal satellite images (case study: Torbat Heydarieh). Journal of Remote Sensing and Geographic Information System in Natural Resources 7(4): 97-115. (In Farsi).

13. Peña, M. A. and A. Brenning. 2015. Assessing fruit-tree crop classification from landsat-8 time series for the Maipo Valley, Chile. Journal of Remote Sensing Environment 171: 234-244.

14. Rahdary, V., S. Maleki, A. Soffianian, J. Khajeddin and A. Pahlevanravi. 2014. Chgange detection of canopy cover percentage using satellite data during 1972-2008 (Case Study: Monteh Wild Life Refuge). Irainian Journal of Rangeland and Desert Research 52(3): 508-521. (In Farsi).

15. Riyahi, V., Z. Firizabadi, P. Azizpour and F. Daroyi. 2019. Determination and investigation cultivation of crops in lanjanat area using satellite imagery. Journal of Applied Research of Geographical Science 19(52): 147-169. (In Farsi).

16. Sawasawa, H. L. A. 2003. Crop yield estimation: integration RS, GIS and management factors. ITC, International Institute for geo-information science and earth observation enschede. The Netherlands.

17. Schowengerdt, R. A. 2007. Remote Sensing: Models and Methods for Image Processing. Academic Press, United States.

18.Tastsumi, K., Y. Yamshiki., M. A. Canales and C. L. Taipe. 2015. Crop classification of upland fields using Random forest of time- series Landsat $7 \mathrm{ETM}^{+}$data. Journal of Computers and Electronics in Agriculture 115: 171-179.

19. Wrighat, G. G. and J. G. Morrice. 1997. Landsat TM spectral information to enhance the land cover of Scotland. International Journal of Remote Sensing 18(18): 3811-3834.

20. Wastfelt, A., T. Tegenu, M. M. Nielsen and B. Malmberg. 2012. Qualitative satellite image analysis: mapping spatial distribution of farming types in Ethiopia. Journal of Applied Geography 2: 465-476. 


\title{
Identification and Investigation of Changes in Area of Hoseynabade Mishmast Village Using Satellite Images
}

\author{
H. Sadoghi*, T. Rajaee and N. Rouhani ${ }^{1}$
}

(Received: March 29-2020 ; Accepted: July 26-2020)

\begin{abstract}
Identification and investigation of changes in the area under cultivation of various crops seem to be essential for the management supply of crop production. In this study, $r$ to identify and investigate change of the area under cultivation in major crop Hoseynabade Mishmast region in Qom province, we used the time series images of OLI and ETM sensors of landsat 8 and 7 satellites, according to the crop calendar of this region. By using the vegetation index (NDVI) in the decision tree algorithm, the thresholds of this index were adjusted according to the major crops of this region; then a map of the cultivation pattern of the crop of this region was prepared. In order to evaluate the results, the statistics of the provinces agricultural jihad were used during 2005, 2009, 2014 and 2019 crop years. The results showed that by using the threshold of NDVI index, crops in this region in 2005 included wheat and barley and alfalfa, and their areas had an error of 17/1 and 6/1 percent in comparison with the statistics of agricultural Jihad, respectively; in 2009, wheat and barley, alfalfa and corn had an error of 0/5, 9/6 and 0/1 percent. Also, in 2014, wheat and barley, alfalfa, corn and sophie crops had an error equal to 4/9, 0.4, 11/4 and 2/4 percent, and the same crops in 2019 had an error 0/04, 11/6, 1/4 and 17/5 percent; that error was not significant. According to the results, the appropriate efficiency NDVI index in estimating crop cultivation area was determined by their phenology. Also, in 2009 and 2014, corn and sophie crops were added to the regions crops, and the area under crops cultivation in 2019 was increased, as compared to 2014.
\end{abstract}

Keywords: NDVI index, Phenology, Cultivation pattern, Decision tree, Hoseynabade Mishmast

1. Department of Civil Engineering, Faculty of Technical and Engineering, Qom university, Iran.

*: Corresponding author, Email: hamideh.sadoghi@gmail.com 